\title{
Self-healing mortar using different types, content, and concentrations of bacteria to repair cracks
}

\author{
Mohamed A.R. Elmahdy \\ Misr Higher Institute of Eng. \& Tech, Elmansura, Egypt \\ Engmohamed_elmabdy@yahoo.com,bttp:/ / orcid.org/0000-0001-5469-6574
}

\author{
A.A. ELShami \\ Housing \& Building National Research Centre, Dokeki, Giza, Egypt \\ materialhnbr@yahoo.com, bttp:/ /orcid.org/0000-0002-9075-7669
}

El-Shikh M. Yousry

Faculty of engineering, El mansura University, Egypt

Mobamed_elshikb@yahoo.com, bttp:/ /orcid.org/0000-0002-0723-2694

Seleem S. E. Ahmad

Faculty of engineering, Zagazig University, Egypt

seleemahmad62@yahoo.com, bttp://orcid.org/0000-0001-9894-0209

\begin{abstract}
The creation of cracks, which are the most common cause of structural failure, has a significant impact on the structure's strength and durability. As a result, effective repair and maintenance are vital and unavoidable for treating any of these issues. Self-healing mortar holds promising benefits for reducing the cost of repair as cracks are autonomously repaired without any human intervention. This study investigated the effect of bacteria type, bacteria content, bacteria concentration, and nutrient type on the properties of the self-healing mortar. Three types of bacteria, Bacillus sphaericus, Bacillus Megaterium and Bacillus subtilis encapsulated in calcium alginate beads, were introduced into the mortar. Two concentrations of bacteria, $2 \times 10^{8}$ and $2 \times 10^{9}$ Colony Forming Units per milliliter $(\mathrm{CFU} / \mathrm{ml})$, and different percentages of bacteria of cement weight were selected for the study. In addition, calcium lactate and calcium acetate were used at $0.5 \%$ of cement weight as nutrition for bacteria. Tests were performed for compressive strength, bending strength, SEM, EDX, and TGA/DTG. The results show a significant development in the mechanical behavior of mortar, especially with Bacillus Megaterium using a $2.5 \%$ bacterial proportion with a concentration $2 \times 10^{9} \mathrm{CFU} / \mathrm{ml}$. This can be related to the filling of voids and cracks in microbial mortar by calcite, which was confirmed by SEM and EDX.
\end{abstract}

\section{OPEN ACCESS}

Citation: Elmahdy, M.A.R., ELShami, A.A., Yousry, E.-S. M., Ahmad, S.S.E., Self-healing mortar using different types, content, and concentrations of bacteria to repair cracks, Frattura ed Integrità Strutturale, 59 (2022) 486-513.

Received: 27.10 .2021

Accepted: 05.12.2021

Published: 01.01.2022

Copyright: (C) 2022 This is an open access article under the terms of the CC-BY 4.0, which permits unrestricted use, distribution, and reproduction in any medium, provided the original author and source are credited. 
KEYwORDS. Self-healing mortar; Bacillus family; Bacterial concentration; Nutrient; Calcite precipitate; Crack filling.

\section{INTRODUCTION}

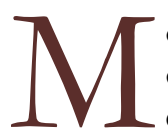

ortar is one of humanity's most widely used construction materials, and it is the main structure used in every country's infrastructure development [1-3]. Permeability or cracks are considered a threat to the structural durability of buildings. They are one of the main causes of mortar deterioration and decrease in durability [4-6]. The porosity and connectivity of the pores affect the permeability of the mortar $[7,8]$. The more open the pore structure of mortar is, the more exposed the material is to penetrating substances' degradation mechanisms [2,9] This fact has motivated researchers to search for ways to produce smart, sustainable, and environmentally friendly concrete materials [10-12]. Different repairing techniques are available to repair the cracks, but they're expensive and time-consuming operations. Self-healing concrete is an advanced technique for repairing cracks in concrete by itself [12].

Self-healing mortar produces calcium carbonate (limestone) biologically to seal pores in the mortar matrix or heal cracks on the surface of mortar structures [13,14]. These microbial deposits may also act as nucleation sites, enhancing early cement hydration and resulting in higher compressive and flexural strengths [15-18]. These self-healing agents can remain dormant in mortar for up to 200 years [19]. Conversely, when mortar structure cracks or is damaged, and water begins to seep through the cracks in the mortar, the bacteria spores germinate on contact with the water and nutrients. When activated, the bacteria begin to consume oxygen while feeding on the calcium-containing nutrient. The soluble calcium nutrition is converted to the insoluble calcium carbonate. Calcium carbonate settles on the cracked surface, filling it up $[20,21]$.

Bacillus is a type of bacteria that can act as a binding filling material to reduce concrete pore structure and improve its strength and durability. Some Bacillus species produce a urease enzyme to precipitate calcite during biomineralization. Specific bacteria types such as Bacillus species, as well as a calcium-based nutrient such as calcium lactate or calcium nitrate, could be introduced to the concrete materials during the mixing process. The use of bacteria to improve performance by reducing the porosity of concrete was evaluated by Parashar et al. They concluded that Bacillus family bacteria were found to be effective concrete healers, and Bacillus megaterium bacteria from the bacillus family can be used efficiently to improve mechanical strength by reducing voids. The compressive strength and water penetration of bio concrete with Enterococcus faecalis and Bacillus sp with the addition of calcium lactate were investigated by Irwan et al. The results of their study show that adding calcium lactate and bacteria to concrete improves the strength and durability of the concrete [22-27]. Bacteria must be able to maintain a high $\mathrm{pH}$ environment in concrete and produce a large amount of $\mathrm{CaCO}_{3}$ in the presence of calcium sources or organic nutrients such as calcium lactate, calcium acetate, calcium glutamate, calcium chloride, and urea [28-30].

However, Sahoo et al. utilise Bacillus Sphaericus in their study to improve cement mortar properties such as compressive strength, and sorptivity. It was discovered that the compressive strength of a mortar increased with the concentration of bacteria after 7 and 28 days. Also, as the concentration of bacterial cells increases, the sorptivity coefficient decreases [31]. In addition to Chaurasia et al. observed that calcium lactate oxidation by Bacillus Megaterium could improve the compressive strength of concrete by $40 \%$ [32]. Moreover, Nagarajan et al. in their research concluded that bacillus megaterium can easily be cultivated and can be used safely to improve the strength characteristics of concrete [33].

For example, Kalhori, et al. investigated the influence of Bacillus Subtilis on the healing and mechanical properties of concrete. The compressive strength of bacterial concrete specimens increased by up to $30 \%$ as compared to control specimens. Bacteria, both in the mix design and the curing solution, were found to increase tensile strength while decreasing water absorption and porosity in shotcrete [34]. Overall, the presence of bacteria improved the mechanical properties of the concrete in terms of compressive strength, according to R. Siddque et al. Also, the water absorption, porosity, and permeability of the concrete were all reduced by the presence of bacteria [35].

In other work, Achal et al. developed a self-healing cement mortar with Bacillus Subtilis and reported that it increased the compressive strength of microbial remediation specimens by up to $40 \%$. Also, they referred to the importance of using bacteria to improve the durability and self-healing ability of cracks in building structures [36].

In the present work, the effect of bacteria type, bacteria content, bacteria concentration, and nutrient type on the properties of the self-healing mortar was experimentally investigated. Three types of bacteria, Bacillus sphaericus, Bacillus Megaterium, and Bacillus subtilis encapsulated in calcium alginate beads, were introduced into the mortar. Two concentrations of bacteria, $2 \times 10^{8}$ and $2 \times 10^{9}(\mathrm{CFU} / \mathrm{ml})$, and different percentages of bacteria of cement weight were 
selected for the study. In comparison with traditional methods, this research introduces a faster technique to fill voids and repair cracks. Also, this research explains in detail how bacteria are prepared and processed. This study ensures the use of ready-prepared powdered bacteria compared to traditional liquid solutions of bacteria that need preparation.

\section{MATERIALS AND METHODS}

\section{Materials}

rdinary Portland (CEM-I 42.5 N) confirmed Egyptian Standard Specifications (4756-1/2007). The chemical analysis and physical properties of the applied cement, as confirmed by laboratory testing (per E.S.S No. 2421/2005), showed its suitability for mortar work. Tab. 1 and Tab. 2 show the properties of the cement used in this research. Clean tap drinking water was used in the mixing. The water to binder ratio $\mathrm{W} / \mathrm{b}$ was 0.35 in all mixes.

\begin{tabular}{cc}
\hline Oxide composition & Percent by Weight $(\%)$ \\
Silicon Oxide $\left(\mathrm{SiO}_{2}\right)$ & 20.37 \\
Aluminum Oxide $\left(\mathrm{Al}_{2} \mathrm{O}_{3}\right)$ & 5.14 \\
Ferric Oxide $\left(\mathrm{Fe}_{2} \mathrm{O}_{3}\right)$ & 3.67 \\
Calcium Oxide $(\mathrm{CaO})$ & 63.51 \\
Magnesium Oxide $(\mathrm{MgO})$ & 1.03 \\
Sulphur Trioxide $\left(\mathrm{SO}_{3}\right)$ & 2.22 \\
Loss on Ignition (L.O.I) & 4.25 \\
\hline
\end{tabular}

Table 1: Chemical composition of the cement.

\begin{tabular}{ccc}
\hline Test & Test result & E.S.S Limits \\
Specific gravity & 3.15 & ---- \\
Specific surface area $\left(\mathrm{cm}^{2} / \mathrm{gm}\right)$ & 3295 & $\geq 2750$ \\
Setting time $(\mathrm{min})$ & Initial & 120 \\
& Final & 360 \\
Compressive strength 3 days $(\mathrm{MPa})$ & 22.6 & $\geq 10 \mathrm{MPa}$ \\
Compressive strength 28days $(\mathrm{MPa})$ & 57.1 & $\geq 42.5 \mathrm{MPa}$ \\
\hline
\end{tabular}

Table 2: Physical and mechanical properties of the cement.

The fine aggregate used in the mortar mix was high-quality natural siliceous sand free of impurities. Testing of the used fine aggregate complied with the Egyptian Standards ES 1109-2008 [37]. The physical properties of used fine aggregate are given in Tab. 3 and the Sieve analysis of sand is given in Tab. 4. The silica fume used in this study as a mineral admixture was brought from Sika Egypt Company. The physical composition of the used silica fume is shown in Tab. 5, as derived from the manufacturer's data sheet. In this study, a high-performance superplasticizer admixture (Sika Viscocrete-3425) was used. It is a superplasticizer of the third generation for homogeneous mixes. It satisfies the superplasticizer standards of ASTM-C-494 types G and F [38]. Tab. 6 shows the properties of superplasticizers used in this work.

\begin{tabular}{ccc}
\hline Property & Sand & Limits* \\
Specific weight & 2.5 & - \\
Bulk density $\left(\mathrm{t} / \mathrm{m}^{3}\right)$ & 1.52 & - \\
Fineness modulus & 3 & - \\
Material finer than No 200 sieve $\%$ & 2.62 & Less than 3\% \\
\hline *The limits according to Egyptian Specification No (1109/2008). \\
Table 3: The physical properties of the fine aggregate 0.
\end{tabular}




\begin{tabular}{ccccccc}
\hline Sieve opening, mm & 5 & 2.36 & 1.18 & .6 & .3 & .15 \\
Passing \% & 98.9 & 95.4 & 80.5 & 40.6 & 25.9 & 8.2 \\
\hline
\end{tabular}

Table 4: Sieve analysis of sand.

\begin{tabular}{cc}
\hline Result* & Property \\
170000 & Surface area $\left(\mathrm{cm}^{2} / \mathrm{gm}\right)$ \\
8.00 & Particle size, $\mu \mathrm{m}$ \\
2.20 & Specific gravity \\
\hline${ }^{*}$ By the manufacture data sheet.
\end{tabular}

Table 5: The physical properties of the used silica fume.

\begin{tabular}{cc}
\hline Result* & Property \\
Clear liquid & Appearance / color \\
1.08 & Density (kg/lit) \\
4.0 & PH value \\
40 & Solid content (\% by weight) \\
\hline \multicolumn{2}{c}{$*$ By the manufacture data-sheet. }
\end{tabular}

Table 6: Properties of the superplasticizers.

Calcium lactate $(\mathrm{Ca} \mathrm{La})$ and calcium acetate $(\mathrm{Ca} \mathrm{Ac})$ was used as bacteria nutrient in this study with a reason of its successful use in bio mortar [27,28] and available in the local market. Three bacteria types were used in this study: two ureolyric bacteria and a ready mix of microcapsules powder bacteria type as shown in Tab. 7.

\begin{tabular}{|c|c|c|c|c|c|}
\hline Type & Name & Number & Designations & Form & Production \\
\hline 1 & $\begin{array}{c}\text { Bacillus sphaericus } \\
\text { (EMCC) }\end{array}$ & EMCC 1253. & $\begin{array}{c}\text { DSM } 396 \text { - NCTC } \\
9602 .\end{array}$ & Solution & Egypt \\
\hline 2 & $\begin{array}{l}\text { Bacillus Megaterium } \\
\text { (BM) }\end{array}$ & ATCC 14581 & $\begin{array}{l}\text { BCRC } 10608 \text { - CCM } \\
2007 \text { - CCUG } 1817- \\
\text { CIP 66.20 - DSM } 32 .\end{array}$ & Solution & Egypt \\
\hline 3 & $\begin{array}{l}\text { Bacillus subtilis } \\
\text { (FP) }\end{array}$ & $\mathrm{H} 50620 / 9$ & 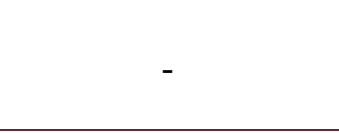 & $\begin{array}{l}\text { Ready mix - Bacteria } \\
\text { encapsulated in Calcium } \\
\text { alginate beads. }\end{array}$ & France \\
\hline
\end{tabular}

Table 7: The description of the used bacteria types.

These types were chosen for the investigation since they have no negative effects on human health and contain a ureasepositive and gram-positive bacterium. Previous research has shown that when given a calcium supply, these gram-positive bacteria can precipitate calcium carbonate through the mineralization process. These two types have a high spore formation capacity that can survive harsh environments, and also the ability to activate when exposed to water, so avoiding the need for a mobilizing agent, makes it a great choice for bio concrete. The BM and EMCC types were obtained from the Microbiological Resources Centre (MIRCEN), Faculty of Agriculture, Ain Shams University, Egypt, while the FP type was exported from France. 


\section{PREPARATION OF CELL SUSPENSION OF BACTERIA}

A

fter receiving the bacteria BM and EMCC stock from the MIRCEN, it was stored in a refrigerator before being opened in sterile conditions. The culture media was made by dissolving 13 grammes of powdered nutrient broth in one litre of distilled water, as recommended by the supplier. The nutrient broth medium used in the preparation process included $2.0 \mathrm{~g} / 1$ yeast extract, $1.0 \mathrm{~g} / 1$ beef extract, $5.0 \mathrm{~g} / 1$ peptone, and $5.0 \mathrm{~g} / 1$ sodium chloride. Previous weights were taken from the manufacturer's data-sheet. Using a $\mathrm{pH}$ metre type AD1030, the $\mathrm{pH}$ value of the culture media was adjusted to $7.2 \pm 0.2$ because it is the ideal environment for the growth of Bacillus genera.

Before usage, all tools used in the preparation process were sterilized by autoclaving one by one. The culture media container had been autoclaved for 20 minutes at $121^{\circ} \mathrm{C}$ and 1.5 bar pressure using an autoclave device type SX-700. The media was then allowed to cool to room temperature after that. The media is now clear of contaminants. Bacteria were removed from the refrigerator and extracted using a loop before being added to the flask tube containing the culture media. This procedure is known as bacteria inoculation, and it takes place inside a device of a laminar flow cabinet type AURA HZ 48 which can provide a contaminant-free working environment. We now have a cell suspension made up of culture media and bacteria. The cell suspension in flasks was then kept for three days in a rotary shaking incubator set to $30^{\circ} \mathrm{C}$ with a shaking rate of $150 \mathrm{rpm}$ to incubate bacteria and activate bacteria growth. The medium became turbid, indicating that bacteria were growing and sporulating. Furthermore, a sample of the media with the bacteria was obtained for light microscopic analysis to evaluate the rate of growth.

Inside a laminar flow cabinet, a loop was used to suspend bacteria in flask tubes containing culture media supplemented with $5 \%$ calcium lactate, and the flasks were then left in a rotary shaking incubator set to $30^{\circ} \mathrm{C}$ and a shaking rate of 150 rpm for 3 days. Calcite production was tested after the incubation period by using $\mathrm{CO}_{2}$ gas generation with the addition of 2 drops of $10 \% \mathrm{HCl}$. Because calcium carbonate dissolves in acid but not in water, the formation of bubbles confirms the existence of calcite. Calcite formation results were observed for bacteria (BM) and (EMCC). The spread plate technique was used to count CFUs using serial dilutions. The spread plate technique was used to count CFUs using serial dilutions. Following the incubation period, a certain amount of culture was taken and its bacterial cells were isolated; these isolated cells were then diluted to the needed volume with distilled water and serially diluted. These isolated cells were then serially dissolved in distilled water to the required volume. The colonies of bacterial cells were counted using solid medium (nutrient agar medium containing 13 grams of nutrient broth dispersed in 1 litre of distilled water and 20 grams of agar powder). To get a cell suspension with a concentration of $\left(2 \times 10^{8}-2 \times 10^{9}\right) \mathrm{CFU} / \mathrm{ml}$ for each type, dilute the cell suspension with culture media, taking into consideration that the amount of nutrient broth per bacterium should be constant across all concentrations. All microbiological tests were performed at Mansoura University's Faculty of Agriculture's Seed and Tissue Pathology Lab, El-Mansoura, Egypt.

\section{DESIGN, MIXING, CASTING PROCEDURE AND CURING}

7 he preliminary mix Proportions were determined and the weight of each component to produce one cubic meter of mortar can be calculated based on the absolute volume method. The mortar mixes proportions are given in Tab. 8. Also, the components of the mixes by weight are shown in Tab. 9.

Fifteen mortar mixtures were designed and tested with varying proportions of four different factors (bacteria content (\%), concentration of bacteria, type of bacteria, and type of nutrient). In all mixes, the sand/cement ratio was 2:1 by weight, the silica fume/cement ratio was $5 \%$, the water/binder ratio was 0.35 and the super plasticizer/cement ratio was $0.50 \%$. Control mix (M0) samples were prepared in the same way without adding bacteria. The nutrient material/cement ratio was $0.5 \%$ in mixes that used BM and EMCC bacteria. The mixtures in which bacteria BM and EMCC were used. The weight of liquid bacteria was deducted from the weight of the water added to the mixture. However, in the case of bacteria FP, the whole weight of water is added to the mixture without being deducted.

The mixing procedure for all mortar mixtures as shown in the following process sequence. Firstly, the calculated quantities of cement and sand were mixed carefully by using a mechanical horizontal pan mixer for two minutes without water. Next, add other fine silica fume and nutrition to the mix and mix for two minutes at low speed. Then, water and super plasticizer were poured over the mixture for approximately five minutes until the mixtures were uniformly distributed. Bacteria liquid of type BM or EMCC is added at the same time as the water is added. However, while bacteria powder of type FP is used, it is added with silica fume and nutrition. Finally, three layers of fresh mortar were being poured into molds and each layer was compacted by using the vibrating Table for $30 \mathrm{~s}$. One of the most significant steps performed 
for self-healing mortar is curing. The specimens were demolded after one day from casting and started curing in tap water until 7, 28, 56, and 90 days for the compressive strength test and 28 and 56 days for the bending strength test.

\begin{tabular}{cccccc}
\hline Mix & $\begin{array}{c}\text { Bacteria } \\
\text { type }\end{array}$ & $\begin{array}{c}\text { Bacteria } \\
\text { concentration } \\
(\text { CFU/ml })\end{array}$ & $\begin{array}{c}\text { Bacteria } \\
\text { /cement }\end{array}$ & $\begin{array}{c}\text { Nutrient } \\
\text { type }\end{array}$ & $\begin{array}{c}\text { Nutrient } \\
\text { /cement }\end{array}$ \\
M0 & - & - & $0.0 \%$ & - & - \\
M1 & BM & $2 \times 10^{8}$ & $0.25 \%$ & Ca La & $0.50 \%$ \\
M2 & BM & $2 \times 10^{9}$ & $0.25 \%$ & Ca La & $0.50 \%$ \\
M3 & EMCC & $2 \times 10^{8}$ & $0.25 \%$ & Ca La & $0.50 \%$ \\
M4 & EMCC & $2 \times 10^{9}$ & $0.25 \%$ & Ca La & $0.50 \%$ \\
M5 & BM & $2 \times 10^{8}$ & $2.5 \%$ & Ca La & $0.50 \%$ \\
M6 & BM & $2 \times 10^{9}$ & $2.5 \%$ & Ca La & $0.50 \%$ \\
M7 & EMCC & $2 \times 10^{8}$ & $2.5 \%$ & Ca La & $0.50 \%$ \\
M8 & EMCC & $2 \times 10^{9}$ & $2.5 \%$ & Ca La & $0.50 \%$ \\
M9 & EMCC & $2 \times 10^{9}$ & $0.25 \%$ & Ca As & $0.50 \%$ \\
M10 & BM & $2 \times 10^{9}$ & $0.25 \%$ & Ca As & $0.50 \%$ \\
M11 & FP & - & $0.25 \%$ & - & - \\
M12 & FP & - & $0.5 \%$ & - & - \\
M13 & FP & - & $2.5 \%$ & - & - \\
M14 & FP & - & $5 \%$ & - & - \\
\hline
\end{tabular}

Table 8: The mortar mixes proportions.

\begin{tabular}{cccccccc}
\hline Mix & $\begin{array}{c}\text { Cement } \\
\left(\mathrm{kg} / \mathrm{m}^{3}\right)\end{array}$ & $\begin{array}{c}\text { Bacteria } \\
\left(\mathrm{kg} / \mathrm{m}^{3}\right)\end{array}$ & $\begin{array}{c}\text { Water } \\
\left(\mathrm{kg} / \mathrm{m}^{3}\right)\end{array}$ & $\begin{array}{c}\text { Nutrient } \\
\left(\mathrm{kg} / \mathrm{m}^{3}\right)\end{array}$ & $\begin{array}{c}\text { Silica } \\
\text { fume } \\
\left(\mathrm{kg} / \mathrm{m}^{3}\right)\end{array}$ & $\begin{array}{c}\text { Super } \\
\text { Plasticizer } \\
\left(\mathrm{kg} / \mathrm{m}^{3}\right)\end{array}$ & $\begin{array}{c}\text { Sand } \\
\left(\mathrm{kg} / \mathrm{m}^{3}\right)\end{array}$ \\
M0 & 701.4 & 0.0 & 257.8 & 0.0 & 35.1 & 3.5 & 1402.9 \\
M1 & 699.2 & 1.7 & 257.0 & 3.5 & 35.0 & 3.5 & 1398.4 \\
M2 & 699.2 & 1.7 & 257.0 & 3.5 & 35.0 & 3.5 & 1398.4 \\
M3 & 699.2 & 1.7 & 257.0 & 3.5 & 35.0 & 3.5 & 1398.4 \\
M4 & 699.2 & 1.7 & 257.0 & 3.5 & 35.0 & 3.5 & 1398.4 \\
M5 & 693.7 & 17.3 & 254.9 & 3.5 & 34.7 & 3.5 & 1387.5 \\
M6 & 693.7 & 17.3 & 254.9 & 3.5 & 34.7 & 3.5 & 1387.5 \\
M7 & 693.7 & 17.3 & 254.9 & 3.5 & 34.7 & 3.5 & 1387.5 \\
M8 & 693.7 & 17.3 & 254.9 & 3.5 & 34.7 & 3.5 & 1387.5 \\
M9 & 699.2 & 1.7 & 257.0 & 3.5 & 35.0 & 3.5 & 1398.4 \\
M10 & 699.2 & 1.7 & 257.0 & 3.5 & 35.0 & 3.5 & 1398.4 \\
M11 & 700.8 & 1.8 & 257.6 & 0.0 & 35.0 & 3.5 & 1401.7 \\
M12 & 700.2 & 3.5 & 257.3 & 0.0 & 35.0 & 3.5 & 1400.4 \\
M13 & 695.3 & 17.4 & 255.5 & 0.0 & 34.8 & 3.5 & 1390.7 \\
M14 & 689.4 & 34.5 & 253.3 & 0.0 & 34.5 & 3.5 & 1378.7 \\
\hline
\end{tabular}

Table 9: The components of the mixes by weight. 


\section{CREATION OF CRACKS}

7 he cubic specimens with dimensions of $70 \times 70 \times 70 \mathrm{~mm}$ were removed from the curing water after 7 days from casting to measure the ultimate load in all mixes, and three specimens of each mix were loaded until failure. Also, according to EC203-2016, specific specimens for cracking were loaded until 30-40\% of the ultimate load was reached, resulting in micro-cracks of various widths in three $7 \mathrm{~cm}$ cubic specimens for each mix, using a hydraulic testing machine with a capacity of $2000 \mathrm{KN}$ and a loading rate in the range of 900-1800 N/S [39]. A visual check of the loaded specimens before and after loading revealed that cracking had occurred. These loaded cracked specimens were returned to curing to allow bacteria to begin precipitating calcite and healing the cracks. Cracked loaded specimens and specimens without pre-cracking from each mix were loaded until failure after 28, 56, 90 days to measure the compressive strength after precipitation calcite.

\section{COMPRESSIVE STRENGTH TEST}

A 11 the specimens were removed from the curing tank before testing and left for about 2 hours to dry in the laboratory. Fresh-water was used for curing. The compressive strength after 7, 28, 56, and 90 days from casting were measured. Three specimen cubes $(7 \times 7 \times 7 \mathrm{~cm})$ from each mixture were tested at each testing age. The compressive test was performed according to EC203-2016 by using a hydraulic testing machine with a capacity of 2000 $\mathrm{KN}$ and an accuracy of $5 \mathrm{KN}$ in the concrete laboratory, faculty of engineering, Zagazig University as shown in Fig.1 [39]. Three specimens were averaged for each mix.
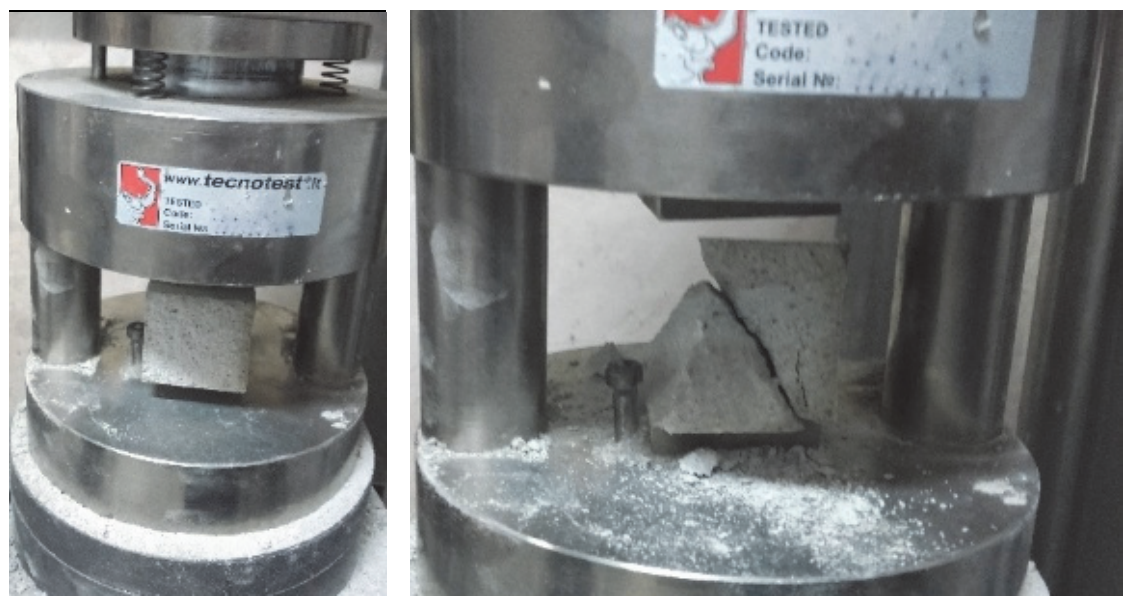

Figure 1: Compression strength test.
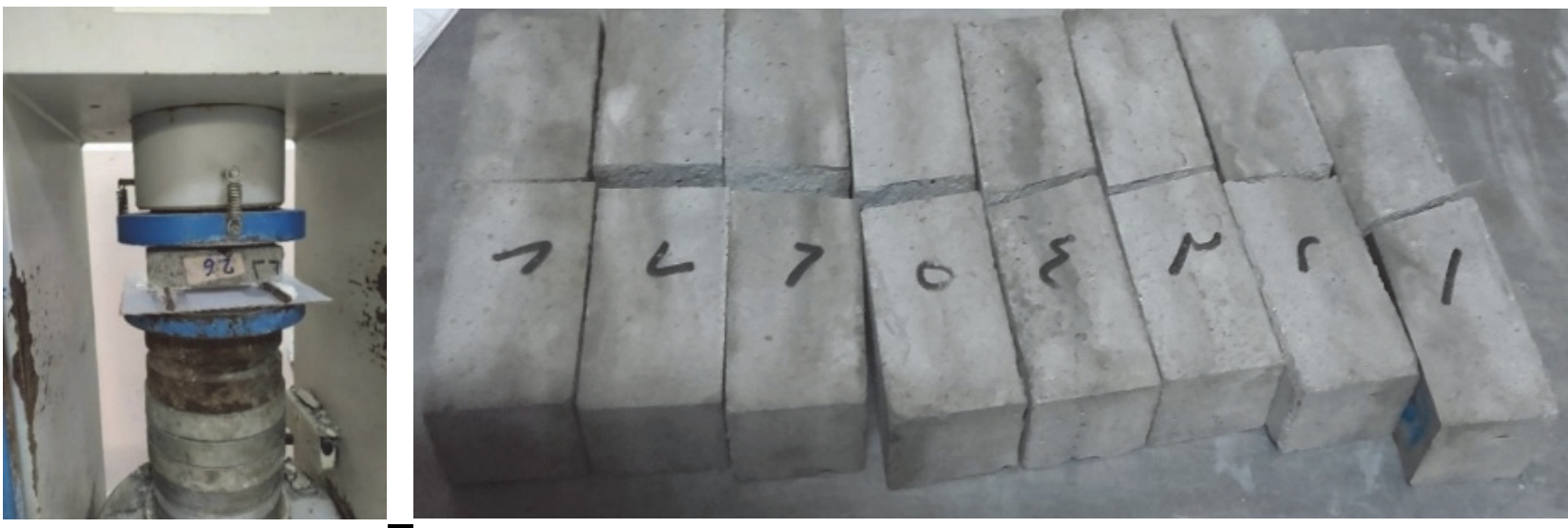

Figure 2: Flexural strength test. 


\section{BENDING STRENGTH TEST}

$\mathrm{B}$ ending strength tests were conducted according to EN 196-1:2016 on prisms of size 40 x 40 x $160 \mathrm{~mm}$ on a hydraulic testing machine with a capacity of $300 \mathrm{KN}$ under a three-point loading test, which was conducted with a loading rate of $5 \mathrm{~N} / \mathrm{cm}^{2} / \mathrm{S}$ as shown in Fig.2. For each mixture, the average of three specimens was calculated. The strength was measured for 28 and 56 days [40].

\section{SCANNING ELECTRON MICROSCOPE (SEM) AND ENERGY-DISPERSIVE X-RAY SPECTROSCOPY (EDS)}

I $\mathrm{n}$ this current study, five mixes M0, M6, M8, M12, and M13 are subjected to a scanning electron microscope (SEM) to analyse the microstructure of mortar. The test was performed using an electronic microscope type JEOL JSM651OLV with a magnification capacity of reaching 300,000 times in the faculty of Agriculture, Mansoura University, Egypt. Five magnifications ranging from 1000X, 1500X, 2000X, 2500X, and 3000X were selected for the observation of specimens. The following is a comprehensive description of the sample preparation procedure. The tested samples of mortar were collected from the innermost core of the crushed specimens after the compressive strength test at the age of 90 days. The samples are dried at $70{ }^{\circ} \mathrm{C}$ until they reach a constant weight, and then the samples are fixed to the holders with glue carbon. In order to get better and clearer microstructure surface imaging, a sputter coating evaporator is used to coat gold on dried samples. Energy-dispersive x-ray spectroscopy (EDS) type (Oxford X-Max 20) was also used to determine the composition of the observed specimens.

\section{THERMO GRAVIMETRIC ANALYSIS (TGA) AND DIFFERENTIAL THERMAL ANALYSIS (DTG)}

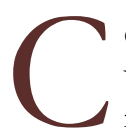
ement paste samples were prepared with water to binder ratio of 0.35 and stored at $20{ }^{\circ} \mathrm{C}$ in $20 \mathrm{~mL}$ sealed plastic vessels for thermogravimetric analysis (TGA), Thermogravimetric analysis was performed on about $50 \mathrm{mg}$ of the resulting powder. It was crushed into small pieces and immediately immersed in acetone to stop hydration and minimize carbonization. Differential Thermal Analysis (DTG) was observed at the age of 28 days after curing. Peaks of temperature were studied. Most endothermic peaks appear at most of their peak temperatures. Decomposition of cement hydrates was shown in TGA tests by declining increments on TGA curves and endothermic peaks on the derivative TGA. Cement hydrate degradation can be divided into three main phases [41]. The first phase represents evaporable water and hydrate decomposition between 25 and $400{ }^{\circ} \mathrm{C}$, the second phase represents dehydroxylation of Portlandite (Ldx) between 400 and $600{ }^{\circ} \mathrm{C}$, and the third phase represents $\mathrm{CaCO}_{3}$ decarbonation between 600 and $800{ }^{\circ} \mathrm{C}$ (Ldc). Between 25 and $400^{\circ} \mathrm{C}$, the first peak can be divided into two phases. Within the temperature range of $25-105{ }^{\circ} \mathrm{C}$, the first phase corresponds to free water, while within the temperature range of $105-400{ }^{\circ} \mathrm{C}$, the dehydration reaction occurs (Ldh). However, the second phase differs from one author to the next. The major distinction between free and chemically bound water is the limit temperature.

\section{RESULTS FOR THE SPECIMENS WITHOUT PRE-CRACKING UNDER COMPRESSION}

$\mathrm{R}$ esults of the influence of bacteria on the compressive strength $(\mathrm{Fcu})$ of mortar at ages 7, 28, 56 and 90 days are given in Tab. 10 and shown in Figs. 3, 4, 5, and 6. The compressive strength results revealed that there was an increase in strength for the bacterial mortar in all mixes when compared to control mix M0.

\section{EFFECT OF BACTERIA CONTENT \%}

$\mathrm{B}$ y examining mortar mixes prepared for this study with different ratios of bacteria, the results revealed that those containing a higher ratio of bacteria gave an increase in compressive strength. When compared to the control mix $\mathrm{M} 0$, the optimum results in increasing compressive strength using BM bacteria were found in mix M6, which contains $2.5 \%$ bacteria $\mathrm{BM} 2 \times 10^{9} \mathrm{CFU} / \mathrm{ml}$ concentration and $0.5 \% \mathrm{Ca} \mathrm{La}$, as shown in Fig.3. The highest compressive strength increase using EMCC bacteria was obtained in mix M8, which contained $2.5 \%$ bacteria $\mathrm{BM}$ at $2 \times 10^{9} \mathrm{CFU} / \mathrm{ml}$ 
concentration and 0.5 percent $\mathrm{Ca}$ La. With the same bacteria, $0.25 \%$ bacteria at a concentration $2 \times 10^{9} \mathrm{CFU} / \mathrm{ml}$ is $\mathrm{more}$ effective than $2.5 \%$ bacteria at a concentration $2 \times 10^{8} \mathrm{CFU} / \mathrm{ml}$. This is an expected result because many bacteria were able to survive through the heat of hydration and the stresses in mortar, and they produced more calcite to fill the pores within the binder matrix, increasing compressive strength. This increase in compressive strength is attributable to the bacteria forming colonies and calcite precipitation in the mortar, which have filled the voids. As a result, the density and strength of the material will also improve [22,42]. On the other hand, using bacteria FP, the increase in compressive strength is significant, using content of $2.5 \%$ and $5 \%$ more than $0.25 \%$ and $0.50 \%$. This increase is related to bacterial calcium carbonate precipitation on the surface and in the pores and cracks of these specimens. Other researchers have also reported similar results $[34,43]$.

\begin{tabular}{lcccccccc}
\hline & Bacteria & \multicolumn{5}{c}{ Fcu (MPa) } & \multicolumn{4}{c}{ Fcu Cracked (MPa) } \\
Mix & type & 7 Days & 28 Days & 56 Days & 90 Days & 28 Days & 56 Days & 90 Days \\
M0 & - & 21 & 25.3 & 28.2 & 30.6 & 15.5 & 16.2 & 16.7 \\
M1 & & 28.6 & 33.6 & 37.9 & 41.2 & 24.2 & 30.7 & 38.6 \\
M2 & BM & 30 & 37.2 & 39.6 & 43.6 & 29.1 & 33.3 & 42.5 \\
M3 & & 23 & 28.3 & 30.3 & 32.5 & 19.6 & 23.7 & 30 \\
M4 & EMCC & 24.6 & 31.6 & 38.4 & 40.6 & 23.4 & 28.8 & 38 \\
M5 & & 29.2 & 35.2 & 39.2 & 42.2 & 27.2 & 33.4 & 40.2 \\
M6 & BM & 31 & 41.8 & 45.4 & 48.6 & 34.3 & 40.5 & 48 \\
M7 & & 22 & 27.5 & 32.6 & 39.8 & 20.1 & 26.1 & 38.1 \\
M8 & EMCC & 25.3 & 36.1 & 41.4 & 47 & 28.4 & 35.6 & 46.4 \\
M9 & & 22.3 & 26.6 & 31.2 & 34.6 & 20.3 & 24.2 & 29.2 \\
M10 & BM & 25.6 & 33.1 & 36 & 37.6 & 26.2 & 30.1 & 33.2 \\
M11 & & 21.6 & 28.7 & 31.5 & 34.6 & 17.5 & 21.8 & 25.5 \\
M12 & \multirow{2}{*}{ FP } & 22 & 30.6 & 32.6 & 35.3 & 19.6 & 23.3 & 28.6 \\
M13 & & 24 & 33.6 & 35.9 & 38.2 & 23.7 & 28.2 & 32.1 \\
M14 & & 24.5 & 36.4 & 38.5 & 43.7 & 24.3 & 30.2 & 37.2 \\
\hline
\end{tabular}

Table 10: Results of compressive strength Fcu (MPa) and compressive strength of reloaded cracked specimens Fcu cracked (MPa).
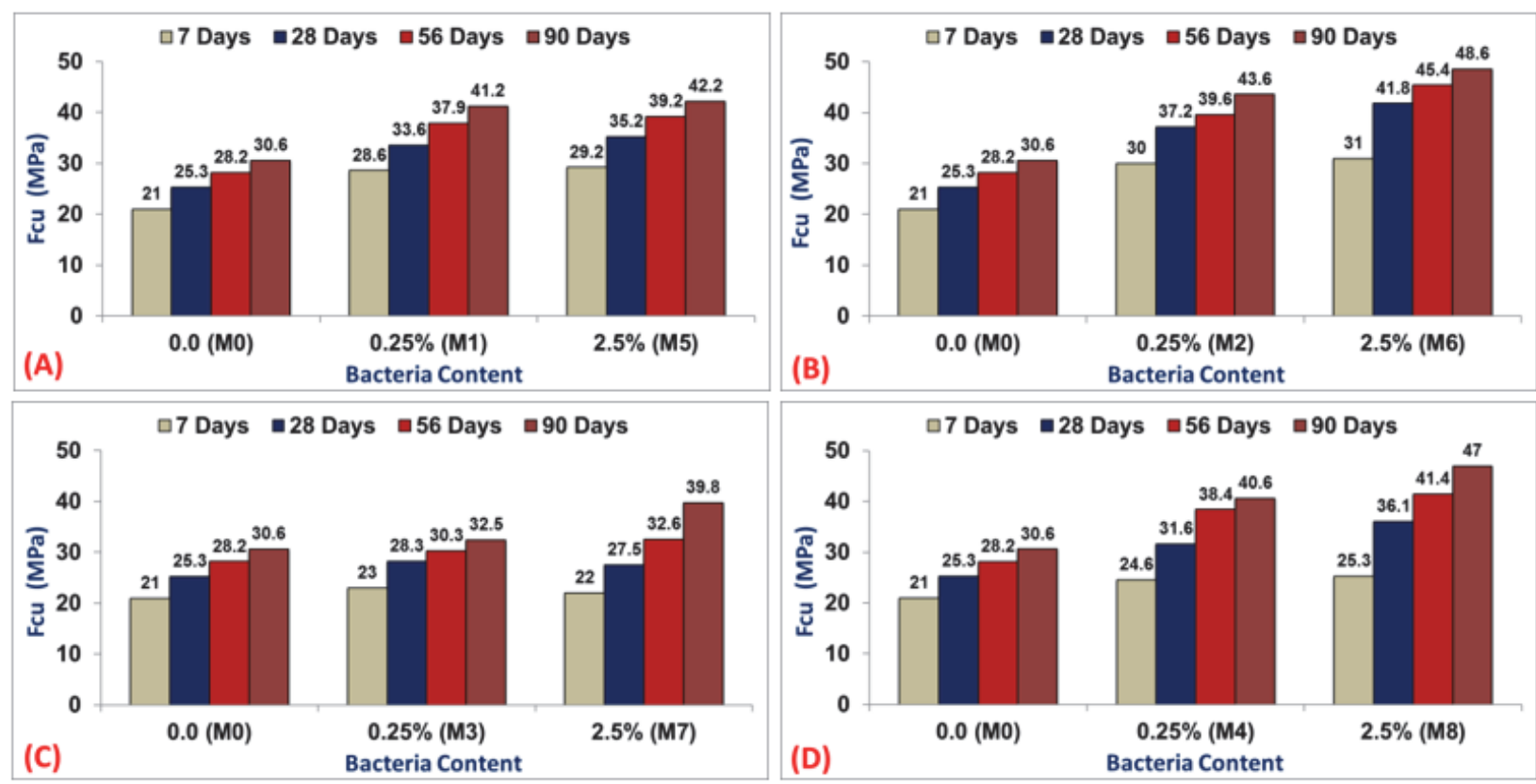


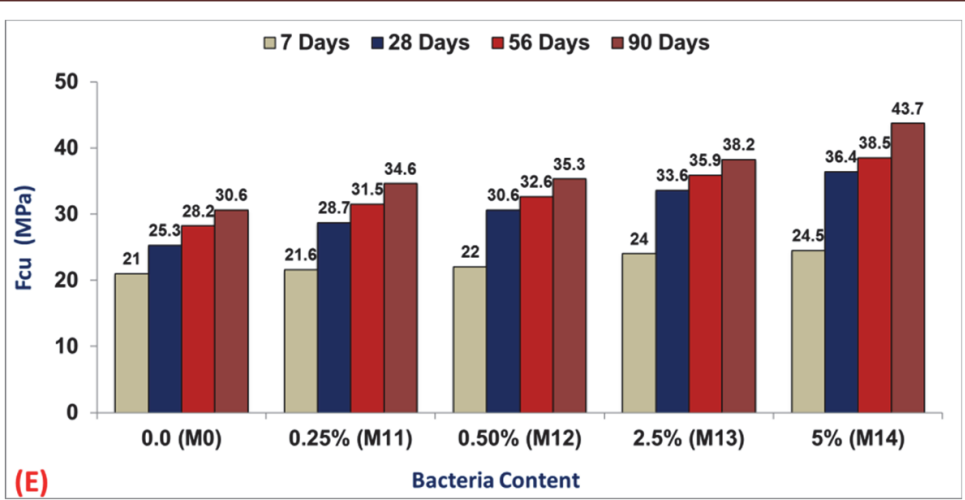

Figure 3: Effect of bacteria content on mortar compressive strength for specimens without pre-cracking, at 7 days, 28 days, 56 days, and 90 days: (A) using a concentration of bacteria $\mathrm{BM}$ of $2 \times 10^{8}$, (B) using a concentration of bacteria $\mathrm{BM}$ of $2 \times 10^{9}$, (C) using a concentration of bacteria EMCC of $2 \times 10^{8}$, (D) using a concentration of bacteria EMCC of $2 \times 10^{9}$, and (E) using bacteria FP.

\section{EFFECT OF BACTERIA CONCENTRATION}

7 he difference in compressive strength is significant when the bacteria concentration is increased to $2 \times 10^{9}$ $\mathrm{CFU} / \mathrm{ml}$. As shown in Fig.4, when using $0.25 \%$ bacteria BM, the difference between mix M1 and mix M2 is 3.6 $\mathrm{MPa}$ after 28 days and $2.4 \mathrm{MPa}$ after 90 days, for example. However, applying $0.25 \%$ bacteria EMCC, the difference between mix M3 and mix M4 is $3.3 \mathrm{MPa}$ after 28 days and $8.1 \mathrm{MPa}$ after 90 days. On the other hand, when the bacteria content is increased from $0.25 \%$ to $2.5 \%$, the difference between mix M5 and mix M6 is $6.6 \mathrm{MPa}$ at 28 days and 6.2 $\mathrm{MPa}$ at 90 days, using 2.5\% bacteria BM. When 2.5\% bacteria EMCC is used, the difference between mixes M7 and M8 is $8.6 \mathrm{MPa}$ at 28 days and $7.2 \mathrm{MPa}$ at 90 days. These findings support the hypothesis that there is a relation between the increase in bacterial concentration and the increase in compressive strength. This improvement was owing to bacteria producing more $\mathrm{CaCO}_{3}$ as a filler material for mortar pores and micro-cavities as a result of their biological activity $[11,15]$.
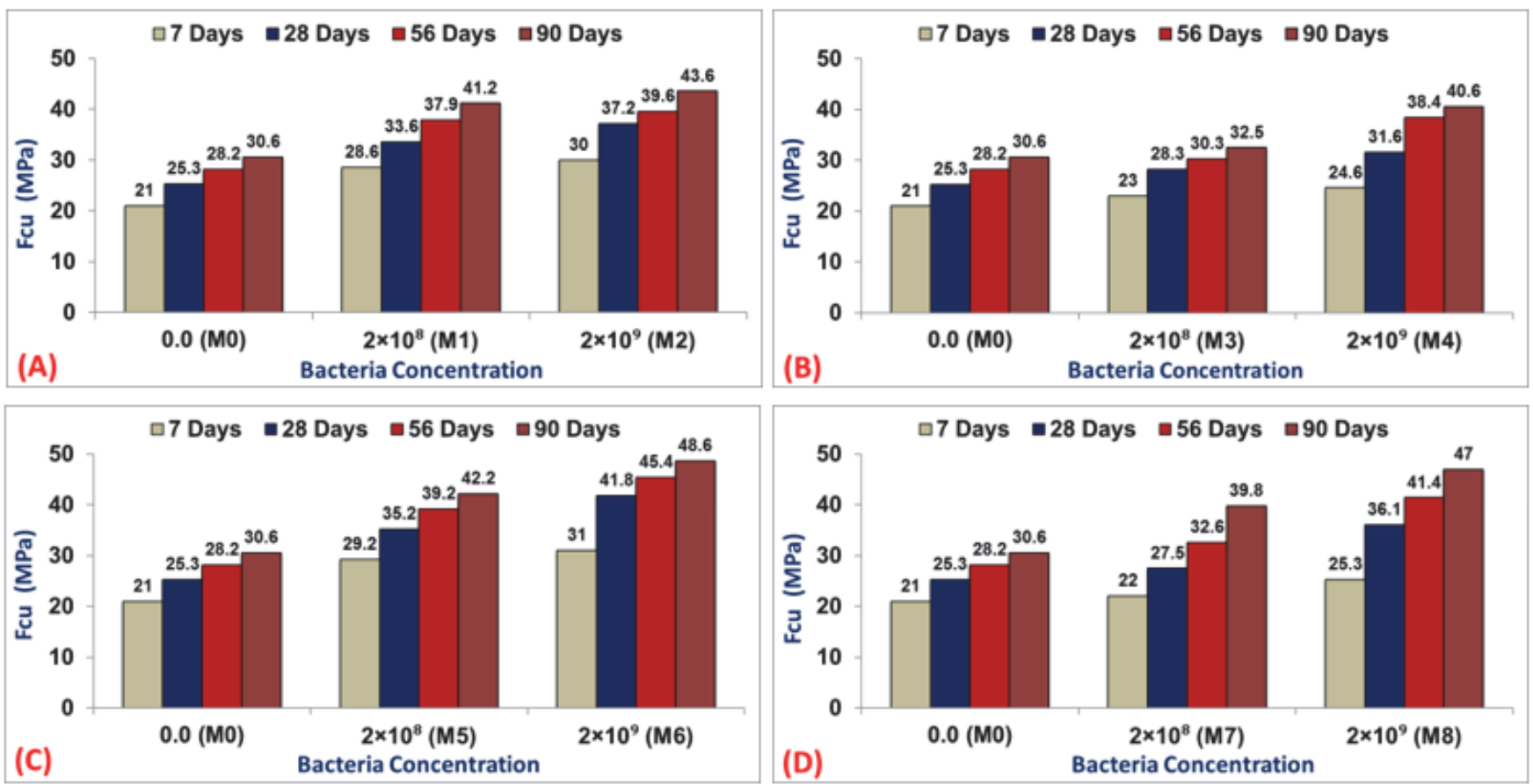

Figure 4: Effect of bacteria concentration on mortar compressive strength for specimens without pre-cracking: (A) using $0.25 \% \mathrm{BM}$, (B) using 0.25\% EMCC, (C) using 2.5\% BM, and (D) using 2.5\% EMCC. 


\section{EFFECT OF BACTERIA TYPE}

W

hen the bacteria type is changed from BM to EMCC, the results demonstrate a difference in compressive strength as shown in Fig.5. In terms of compressive strength, the BM type generally surpasses the EMCC type. Using bacteria at a concentration of $2 \times 10^{9} \mathrm{CFU} / \mathrm{ml}$ and $0.50 \% \mathrm{Ca} \mathrm{La}$, the difference in compressive strength between mix M6 and mix M8 at 28 days is $5.7 \mathrm{MPa}$ and $1.6 \mathrm{MPa}$ at 90 days. This was BM's gain. When the nutrient is changed to $\mathrm{Ca}$ Ac, the difference between mix M9 and mix M10 is $6.5 \mathrm{MPa}$ at 28 days and $3 \mathrm{MPa}$ at 90 days when using $2.5 \%$ bacteria at a concentration of $2 \times 10^{9} \mathrm{CFU} / \mathrm{ml}$ and $0.50 \% \mathrm{Ca}$ Ac. Bacillus megaterium bacteria were found to produce more calcium carbonate and were capable of filling the pores [26,33].
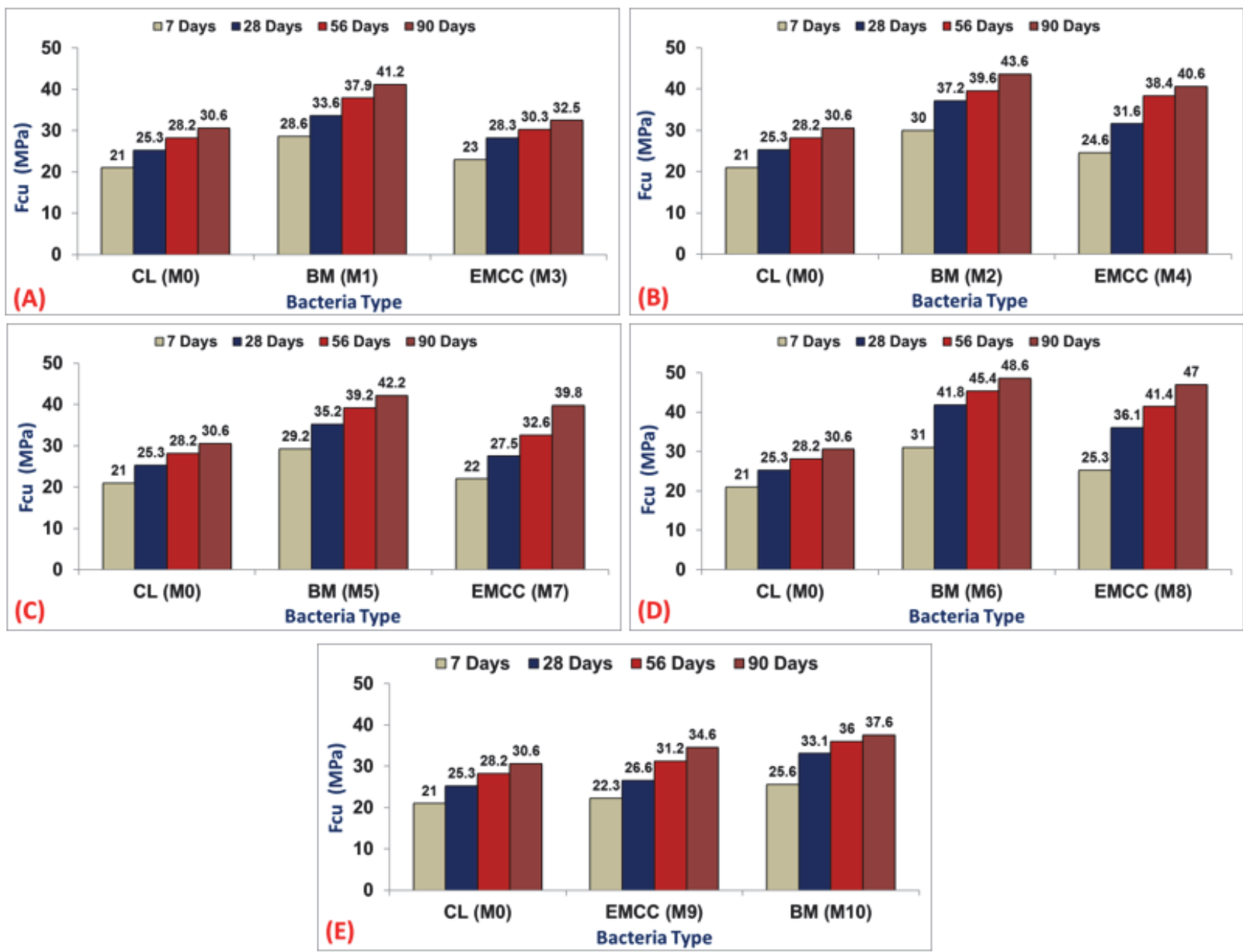

Figure 5: Effect of bacteria type on mortar compressive strength for specimens without pre-cracking, at 7 days, 28 days, 56 days, and 90 days: (A) $0.25 \%$ bacteria $2 \times 10^{8}$ concentration $+0.50 \% \mathrm{Ca} \mathrm{La}$; (B) $0.25 \%$ bacteria $2 \times 10^{9}$ concentration $+0.50 \% \mathrm{Ca} \mathrm{La}$; (C) $2.5 \%$ bacteria $2 \times 10^{8}$ concentration $+0.50 \% \mathrm{Ca} \mathrm{La}$; (D) $2.5 \%$ bacteria $2 \times 10^{9}$ concentration $+0.50 \% \mathrm{Ca} \mathrm{La}$; and (E) $0.25 \%$ bacteria $2 \times 10^{9}$ concentration $+0.50 \% \mathrm{Ca}$ Ac.

\section{EFFECT OF NUTRIENT TYPE}

$\mathrm{F}$ ig.6 represents the differences between $\mathrm{Ca} \mathrm{La}$ and $\mathrm{Ca}$ Ac nutrient materials. The difference between mix M2 and mix M10 after 28 days and 90 days using $0.25 \% \mathrm{BM}$ bacteria at a concentration of $2 \times 10^{9} \mathrm{CFU} / \mathrm{ml}$ is $4.1 \mathrm{MPa}$ and $6 \mathrm{MPa}$, respectively. When $0.25 \%$ EMCC bacteria with a concentration of $2 \times 10^{9} \mathrm{CFU} / \mathrm{ml}$ are used, the difference between M4 and M9 at 28 days is $5 \mathrm{MPa}$, and at 90 days, it is $6 \mathrm{MPa}$. The efficiency of nutrients is also reported by other researchers $[1,27,44]$. 

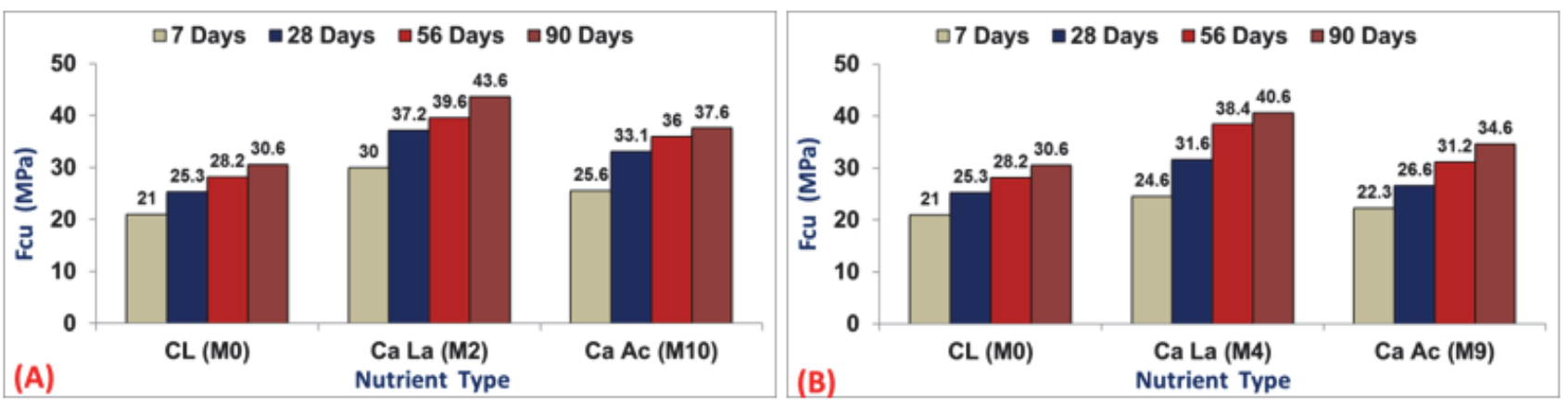

Figure 6: Effect of nutrient type on mortar compressive strength for specimens without pre-cracking, at 7 days, 28 days, 56 days and 90 days: (A) using $0.25 \% \mathrm{BM}$ with a concentration of $2 \times 10^{9}$ and (B) using $0.25 \%$ EMCC with a concentration of $2 \times 10^{9}$.

\section{RESULTS FOR THE PRE-CRACKED SPECIMENS UNDER COMPRESSION}

$\mathrm{C}$ ompressive strength values of specimens without pre-cracking were compared to reloaded cracked specimens. Results of compressive strength test for reloaded cracked specimens containing bacteria indicated that there was an increase in strength when compared to the specimens without pre-cracking of the same mix at the age of 28, 56, and 90 days as illustrated in Tab. 10 and is shown in Figs. 7:22. This indicates that internal micro-cracks caused by loading have the ability to heal and the ability to restore the mechanical properties of mortar to their original state by using bacteria $[36,45,46]$.

\section{EFFECT OF BACTERIA CONTENT \%}

he results of the compressive strength show the effect of the bacteria content on the recovery of reloaded cracked samples' compressive strength. As the content of bacteria increases, the recovery ratio of compressive strength of the reloaded cracked samples compared to the unloaded samples of the same mixture increases. For example, when using bacteria BM with a concentration of $2 \times 10^{9}$, the compressive strength of the reloaded cracked samples compared to the unloaded samples is equal to $61.26 \%, 78.22 \%$, and $82.1 \%$, respectively at age of 28 days and equal to $57.45 \%, 84.1 \%$, and $89.2 \%$, respectively at age of 56 days and equal to $54.58 \%, 97.77 \%$, and $98.8 \%$, respectively at age of 90 days in mixes M0, M2, and M6 respectively. The recovery of the compressive strength of the mortar increased with the increase in the content of bacteria. [1,45]. On another hand, using the FP bacteria, the recovery ratio of compressive strength of the reloaded cracked samples compared to the unloaded samples in mix M11 using $0.25 \%$ of bacteria FP is equal to $64.05 \%, 71.47 \%$, and $81.02 \%$ at age of 28,56 , and 90 days respectively. While the recovery ratio is equal to $70.54 \%, 78.55 \%$, and $84 \%$ at the ages of 28,56 , and 90 days respectively, using $2.5 \%$ bacteria in mix M13. The results confirmed that the precipitation in the cracks is calcium carbonate and is consistent with the results achieved by other researchers $[36,43]$.
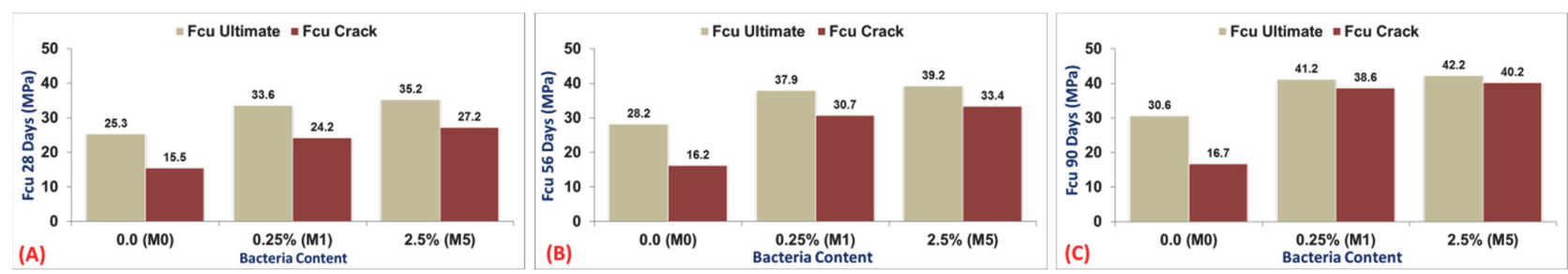

Figure 7: Effect of bacteria content on compressive strength results for reloaded cracked specimens and specimens without precracking using $2 \times 10^{8}$ concentration of bacteria BM and $0.5 \%$ Ca La: (A) at 28 days, (B) at 56 days, and (C) at 90 days. 

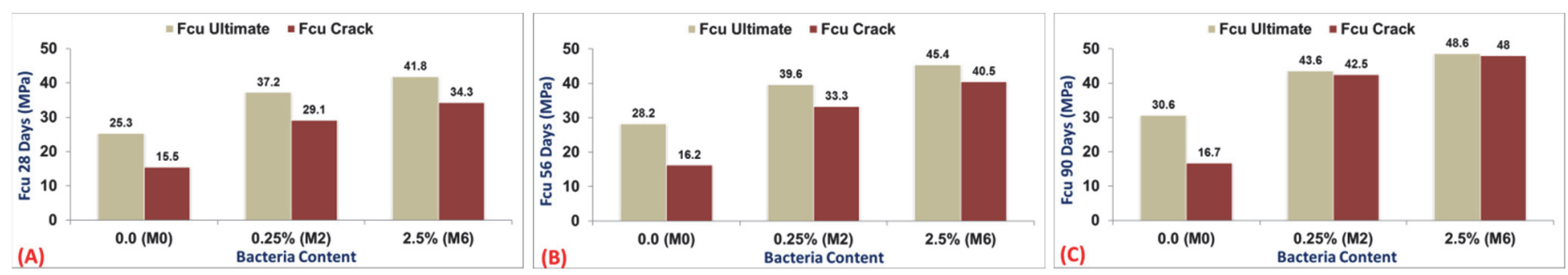

Figure 8: Effect of bacteria content on compressive strength results for reloaded cracked specimens and specimens without precracking using $2 \times 10^{9}$ concentration of bacteria BM and $0.5 \%$ Ca La: (A) at 28 days, (B) at 56 days, and (C) at 90 days.
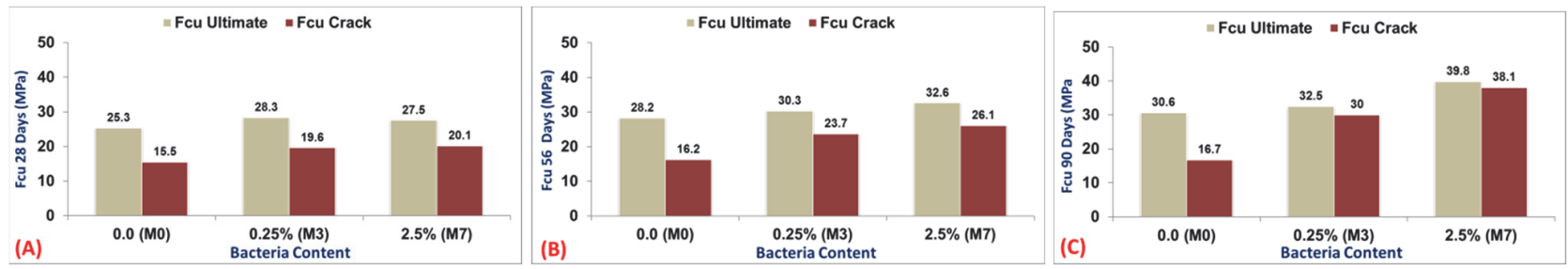

Figure 9: Effect of bacteria content on compressive strength results for reloaded cracked specimens and specimens without precracking using $2 \times 10^{8}$ concentration of bacteria EMCC and $0.5 \%$ Ca La: (A) at 28 days, (B) at 56 days, and (C) at 90 days.
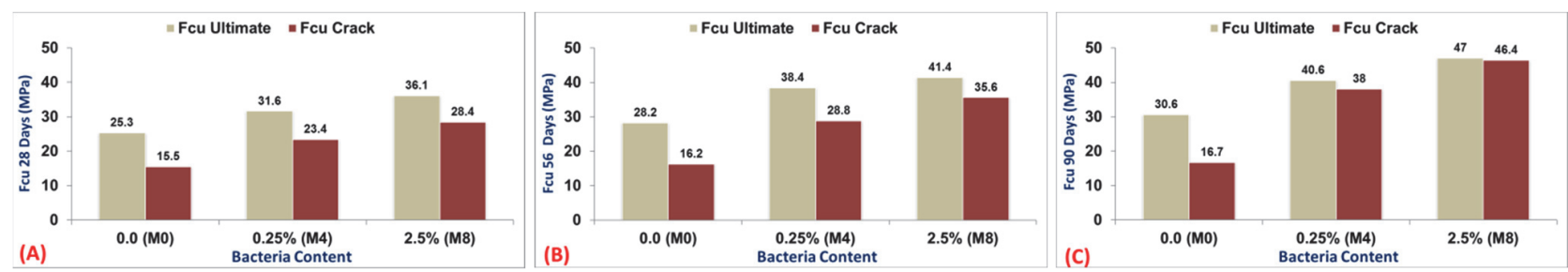

Figure 10: Effect of bacteria content on compressive strength results for reloaded cracked specimens and specimens without precracking using $2 \times 10^{9}$ concentration of bacteria EMCC and $0.5 \%$ Ca La: (A) at 28 days, (B) at 56 days, and (C) at 90 days.
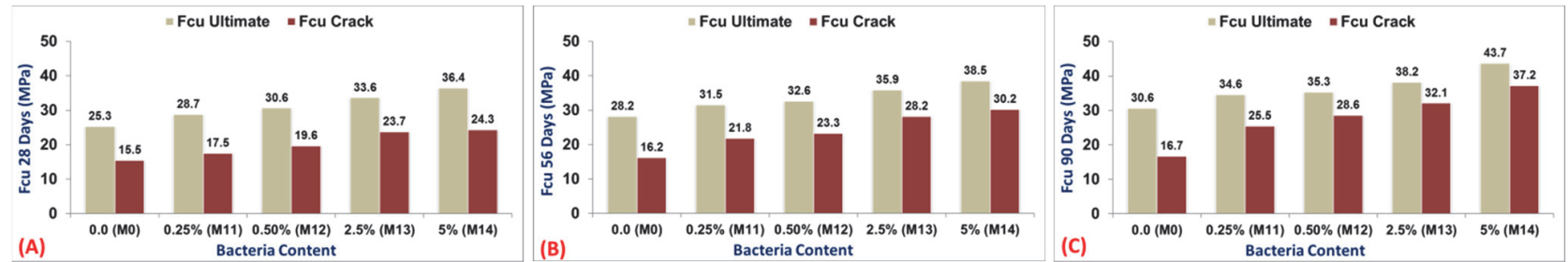

Figure 11: Effect of bacteria content on compressive strength results for reloaded cracked specimens and specimens without precracking using bacteria FP: (A) at 28 days, (B) at 56 days, and (C) at 90 days.

\section{EFFECT OF BACTERIA CONCENTRATION}

7 he concentration of bacteria has a main effect on sample recovery for compressive strength. As shown in Figs. 12:15, compressive strength of cracked samples compared to the unloaded samples at 90 days was equal to $93.69 \%, 92.31 \%, 98.77 \%$, and $98.72 \%$ for mixes M1, M3, M5, and M7, respectively, using $2 \times 10^{8} \mathrm{CFU} / \mathrm{ml}$ concentration. However, using $10^{9}$ concentration, the compressive strength of cracked samples compared to the unloaded samples at 90 days for mixes M2, M4, M6, and M8 was equal to $97.48 \%, 93.60 \%, 98.77 \%$, and $98.72 \%$ respectively. The results were because the highest concentration of spores was capable of producing more crystals that could increase the ability to fill cracks and recover strength $[1,31,47]$. 

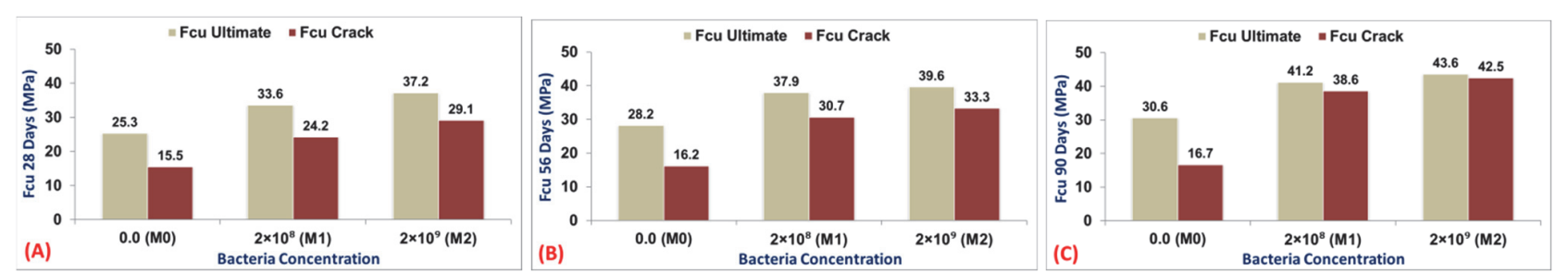

Figure 12: Effect of bacteria concentration on compressive strength results for reloaded cracked specimens and specimens without pre-cracking using $0.25 \%$ bacteria $\mathrm{BM}$ and $0.5 \% \mathrm{Ca} \mathrm{La:} \mathrm{(A)} \mathrm{at} 28$ days, (B) at 56 days, and (C) at 90 days.
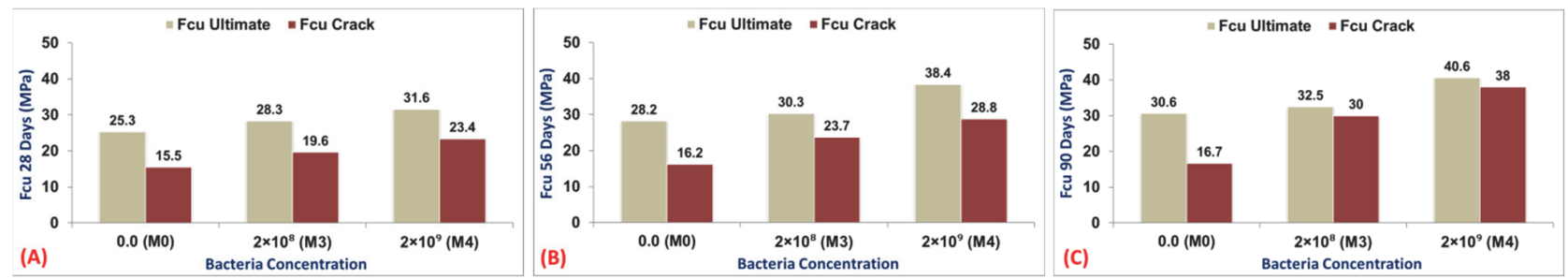

Figure 13: Effect of bacteria concentration on compressive strength results for reloaded cracked specimens and specimens without pre-cracking using $0.25 \%$ bacteria EMCC and $0.5 \%$ Ca La: (A) at 28 days, (B) at 56 days, and (C) at 90 days.
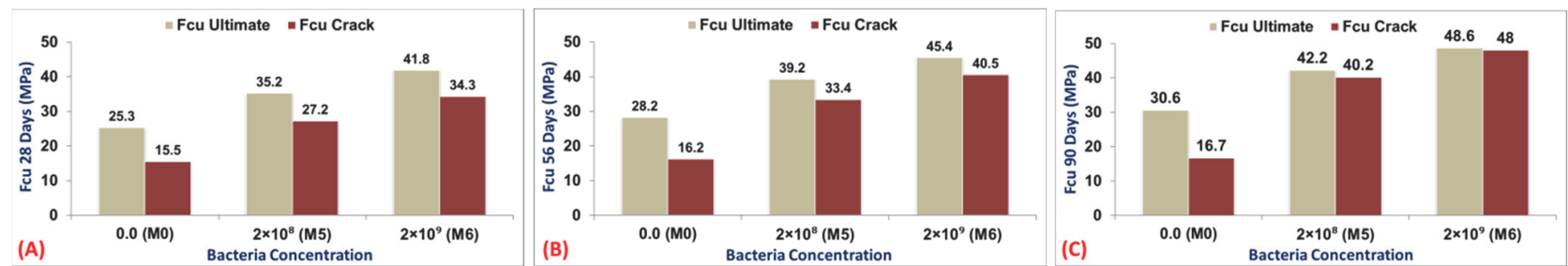

Figure 14: Effect of bacteria concentration on compressive strength results for reloaded cracked specimens and specimens without pre-cracking using $2.5 \%$ bacteria $\mathrm{BM}$ and $0.5 \% \mathrm{Ca}$ La: (A) at 28 days, (B) at 56 days, and (C) at 90 days.
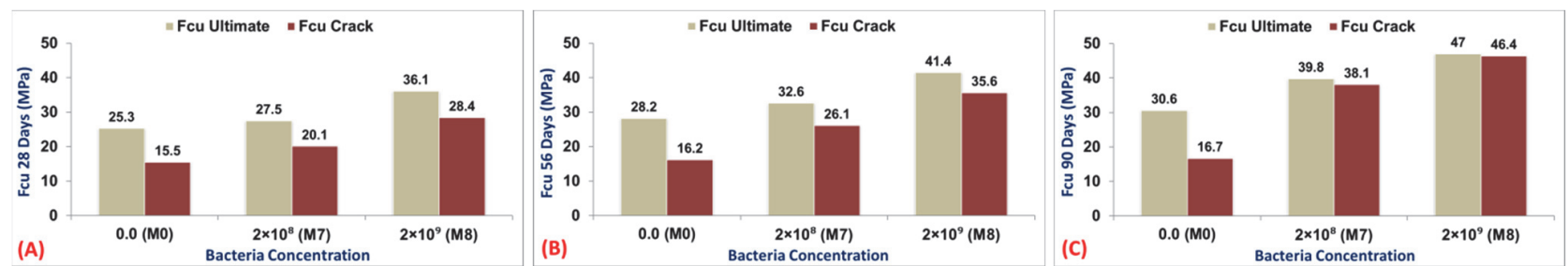

Figure 15: Effect of bacteria concentration on compressive strength results for reloaded cracked specimens and specimens without pre-cracking using $2.5 \%$ bacteria EMCC and $0.5 \% \mathrm{Ca}$ La: (A) at 28 days, (B) at 56 days, and (C) at 90 days.

\section{EFFECT OF BACTERIA TYPE}

7 he results showed that using bacteria increased the compressive strength of reloaded cracked specimens so close to the specimens without pre-cracking compared with control mix with a percentage reaching to $82 \%, 89.2 \%$, and $98.77 \%$ of ultimate compressive strength at ages of 28,56 , and 90 days respectively for M6 using bacteria BM. On the other hand, when using bacteria EMCC, the compressive strength of reloaded cracked specimens reaches $78.7 \%, 86$ and $98.72 \%$ of ultimate compressive strength at ages of 28,56 and 90 days, respectively for M8. Also, using bacteria FP, the compressive strength of reloaded cracked specimens reached $66.8 \%, 78.4 \%$ and $85.1 \%$ of ultimate compressive strength at ages of 28, 56 and 90 days, respectively for M14. Overall, the increase in compressive strength for reloaded cracked specimens increases with the increase in the age of specimens. The results confirm that the Bacillus megaterium bacteria of the bacillus family was found to be effective in improving mechanical strength by reducing voids $[26,33,34,48]$. 

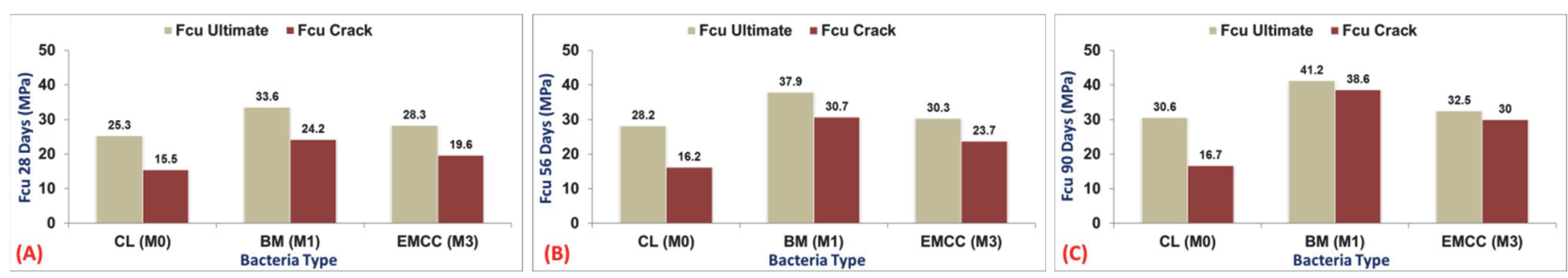

Figure 16: Effect of bacteria type on compressive strength results for reloaded cracked specimens and specimens without pre-cracking using $0.25 \%$ bacteria and a concentration of $2 \times 10^{8}+0.50 \%$ Ca La: (A) at 28 days, (B) at 56 days, and (C) at 90 days.
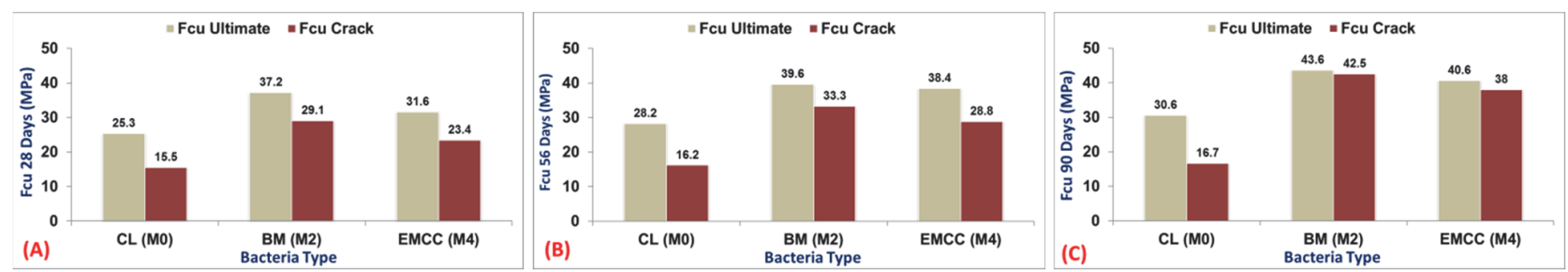

Figure 17: Effect of bacteria type on compressive strength results for reloaded cracked specimens and specimens without pre-cracking using $0.25 \%$ bacteria and a concentration of $2 \times 10^{9}+0.50 \%$ Ca La: (A) at 28 days, (B) at 56 days, and (C) at 90 days.
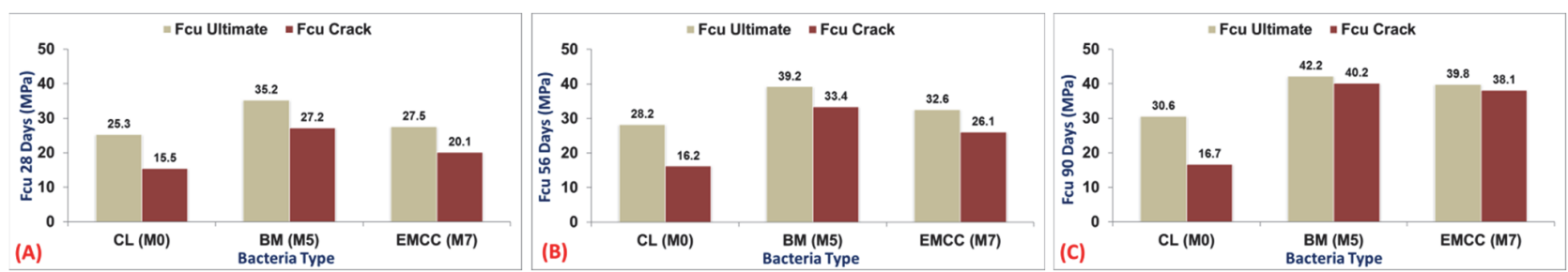

Figure 18: Effect of bacteria type on compressive strength results for reloaded cracked specimens and specimens without pre-cracking using $2.5 \%$ bacteria and a concentration of $2 \times 10^{8}+0.50 \%$ Ca La: (A) at 28 days, (B) at 56 days, and (C) at 90 days.
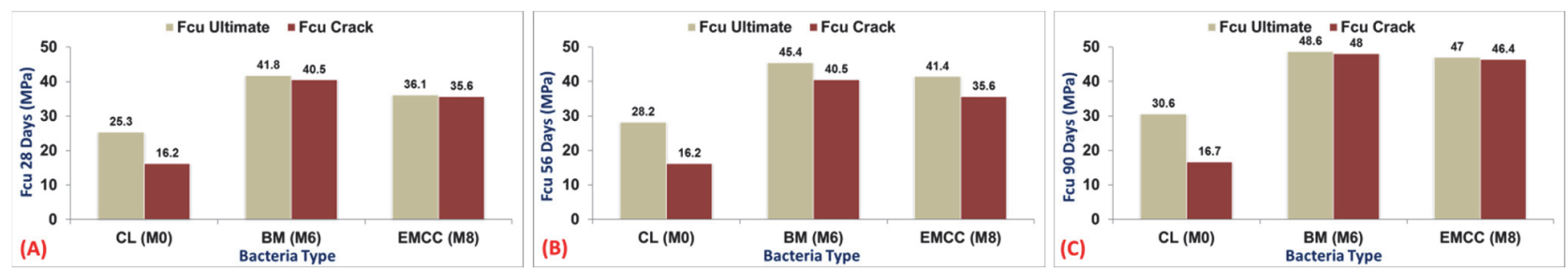

Figure 19: Effect of bacteria type on compressive strength results for reloaded cracked specimens and specimens without pre-cracking using $2.5 \%$ bacteria and a concentration of $2 \times 10^{9}+0.50 \%$ Ca La: (A) at 28 days, (B) at 56 days, and (C) at 90 days.
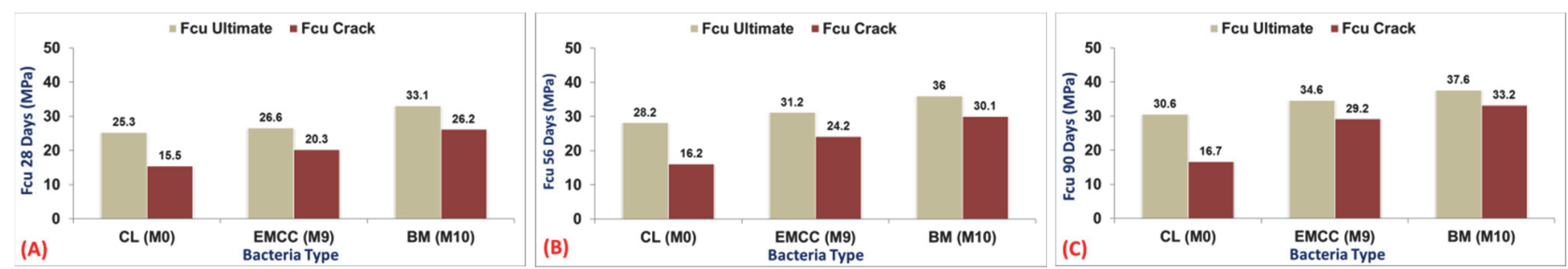

Figure 20: Effect of bacteria type on compressive strength results for reloaded cracked specimens and specimens without pre-cracking using $0.25 \%$ bacteria and a concentration of $2 \times 10^{9}+0.50 \% \mathrm{Ca}$ Ac: $(\mathrm{A})$ at 28 days, (B) at 56 days, and (C) at 90 days. 


\section{EFFECT OF NUTRIENT TYPE}

$\mathrm{R}$ esults indicate that $\mathrm{Ca} \mathrm{La}$ use is more effective than $\mathrm{Ca} \mathrm{Ac}$ use in recovering cracked samples for compressive strength, as shown in Figs. 21, and 22. By way of explanation, at age 90 days when using $\mathrm{Ca} \mathrm{La}$ as a nutrient, the compressive strength of cracked samples compared to the unloaded samples at was equal to $97.84 \%$, and $93.6 \%$ for M2 and M4 respectively, while was equal $88.30 \%$, and 84.39 for M10, and M9 respectively using Ca Ac. Other researchers have also reported on the efficiency of nutrients $[1,27,44]$.
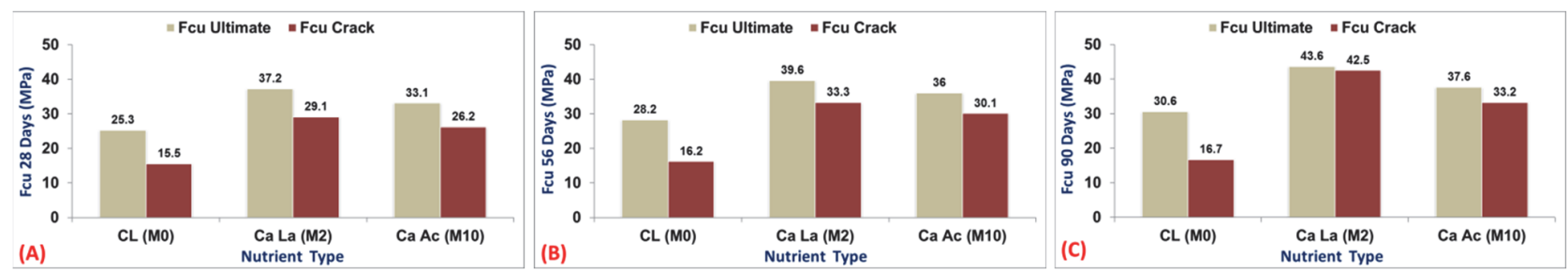

Figure 21: Effect of nutrient type on compressive strength results for reloaded cracked specimens and specimens without pre-cracking using $0.25 \%$ bacteria $\mathrm{BM}$ with a concentration of $2 \times 10^{9}$ : (A) at 28 days, (B) at 56 days, and (C) at 90 days.
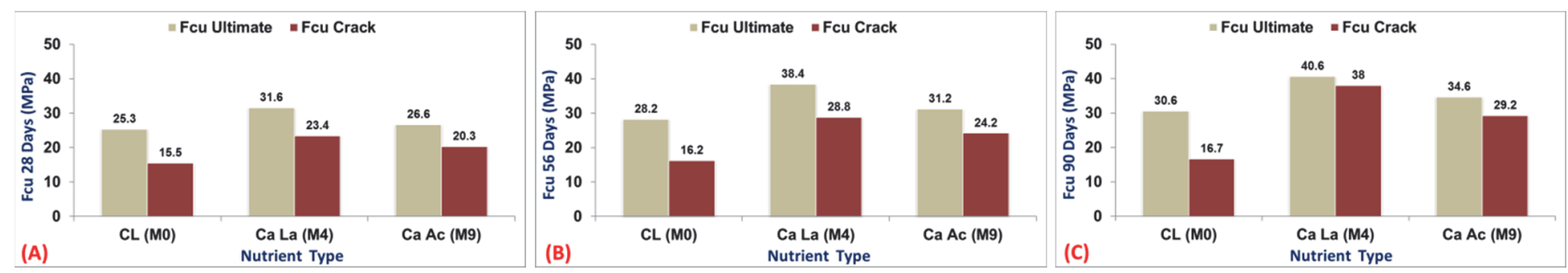

Figure 22: Effect of nutrient type on compressive strength results for reloaded cracked specimens and specimens without pre-cracking using $0.25 \%$ bacteria EMCC with a concentration of $2 \times 10^{9}$ : (A) at 28 days, (B) at 56 days, and (C) at 90 days.

\section{BENDING STRENGTH RESULTS}

7 he effect of bacteria content, bacteria concentration, type of bacteria and type of nutrient on bending strength was investigated at ages of 28 and 56 days as shown in Figs. 23:26. The results revealed that there was a significant increase in strength for bacterial mortar in all mixes.

\begin{tabular}{|c|c|c|c|c|c|}
\hline \multicolumn{4}{|c|}{$\mathrm{Fb}(\mathrm{MPa})$} & \multicolumn{2}{|c|}{$\mathrm{Fb}(\mathrm{MPa})$} \\
\hline Mix & $\begin{array}{c}28 \\
\text { Days }\end{array}$ & $\begin{array}{c}56 \\
\text { Days }\end{array}$ & Mix & $\begin{array}{c}28 \\
\text { Days }\end{array}$ & $\begin{array}{c}56 \\
\text { Days }\end{array}$ \\
\hline M0 & 7.88 & 8.5 & M8 & 10.92 & 13.26 \\
\hline M1 & 7.88 & 9.19 & M9 & 8.12 & 10.31 \\
\hline M2 & 10.83 & 12.8 & M10 & 8.53 & 10.86 \\
\hline M3 & 8.53 & 9.52 & M11 & 8.86 & 11.48 \\
\hline M4 & 10.06 & 12.23 & M12 & 9.84 & 12.14 \\
\hline M5 & 9.63 & 11.81 & M13 & 10.83 & 13.78 \\
\hline M6 & 12.34 & 14.77 & M14 & 13.24 & 17.72 \\
\hline M7 & 9.84 & 11.16 & & & \\
\hline
\end{tabular}

Table 11: Results of bending strength $\mathrm{Fb}(\mathrm{MPa})$. 


\section{EFFECT OF BACTERIA CONTENT \%}

$\mathrm{U}$ sing bacteria $\mathrm{BM}$, the best bacteria content when compared to control mix M0 is $2.5 \%$ in mix M6, with an increase of $56.6 \%$ and $71.7 \%$ at 28 and 56 days, respectively. Using bacteria EMCC, the best bacteria content when compared to control mix M0 is $2.5 \%$ in mix M8, with an increase of $38.6 \%$ and $54.2 \%$ at 28 and 56 days, respectively. The amount of $\mathrm{CaCO}_{3}$ precipitated in the mortar has a positive effect on its flexural strength $[45,47,49]$. On the other hand, when comparing bacteria FP to control mix M0, 5\% in mix M14 was the best content, with increases of $68 \%$ and $108.5 \%$ at 28 and 56 days, respectively. The increase in strength using FP bacteria confirms the fact that crystals are precipitated by the bacteria in mortar matrix and calcium carbonate stands out as reported by other researchers $[3,34,42]$.
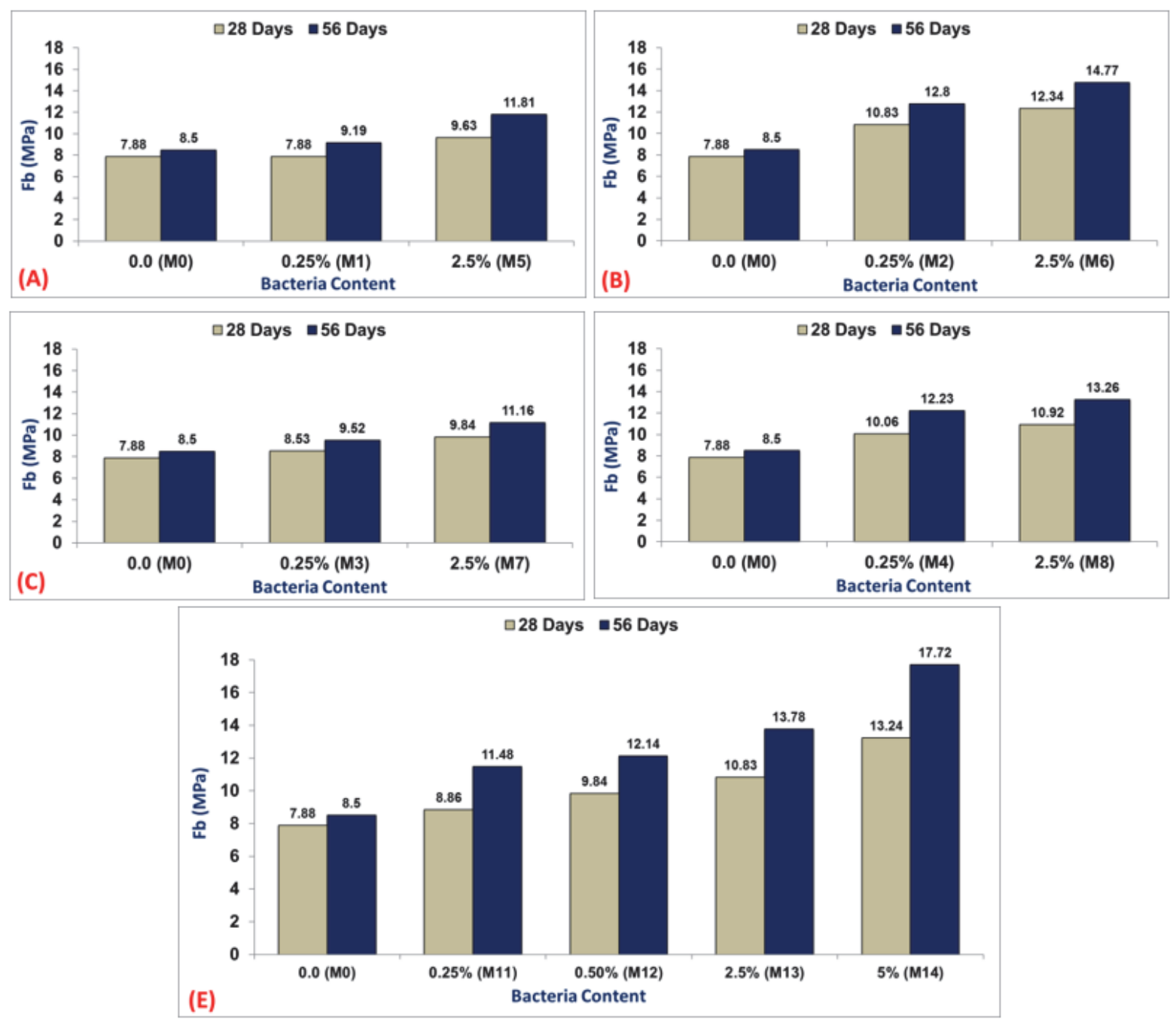

Figure 23: Effect of bacteria type on mortar bending strength for specimens without pre-cracking, at 7 days, 28 days, 56 days, and 90 days: (A) using $2 \times 10^{8}$ concentration of bacteria BM, (B) using $2 \times 10^{9}$ concentration of bacteria $\mathrm{BM}$, (C) using $2 \times 10^{8}$ concentration of bacteria EMCC, (D) using $2 \times 10^{9}$ concentration of bacteria EMCC and (E) using bacteria FP.

\section{EFFECT OF BACTERIA CONCENTRATION}

7 he bending strength values increase as the bacteria concentration rises to $2 \times 10^{9} \mathrm{CFU} / \mathrm{ml}$. Using $0.25 \%$ bacteria $\mathrm{BM}$, for example, the difference between mixes $\mathrm{M} 1$ and $\mathrm{M} 2$ is $3.95 \mathrm{MPa}$ at 28 days and $3.61 \mathrm{MPa}$ at 56 days. Utilizing $0.25 \%$ bacteria EMCC, the difference between mixes M3 and M4 after 28 days is $1.53 \mathrm{MPa}$ and $2.71 \mathrm{MPa}$ 
after 56 days. Whenever the bacteria content increases from $0.25 \%$ to $2.5 \%$, using $\%$ bacteria $\mathrm{BM}$, the difference between mix M5 and mix M6 is $2.71 \mathrm{MPa}$ at 28 days and $2.96 \mathrm{MPa}$ at 56 days. Furthermore, using $2.5 \%$ bacteria EMCC, the distinction between mixes M7 and M8 is $1.08 \mathrm{MPa}$ at 28 days and $2.1 \mathrm{MPa}$ at 56 days. The increase in flexural strength is due to the bacteria-precipitated materials being involved in the hydration process, resulting in the formation of C-S-H, which is responsible for strength development $[15,49]$.
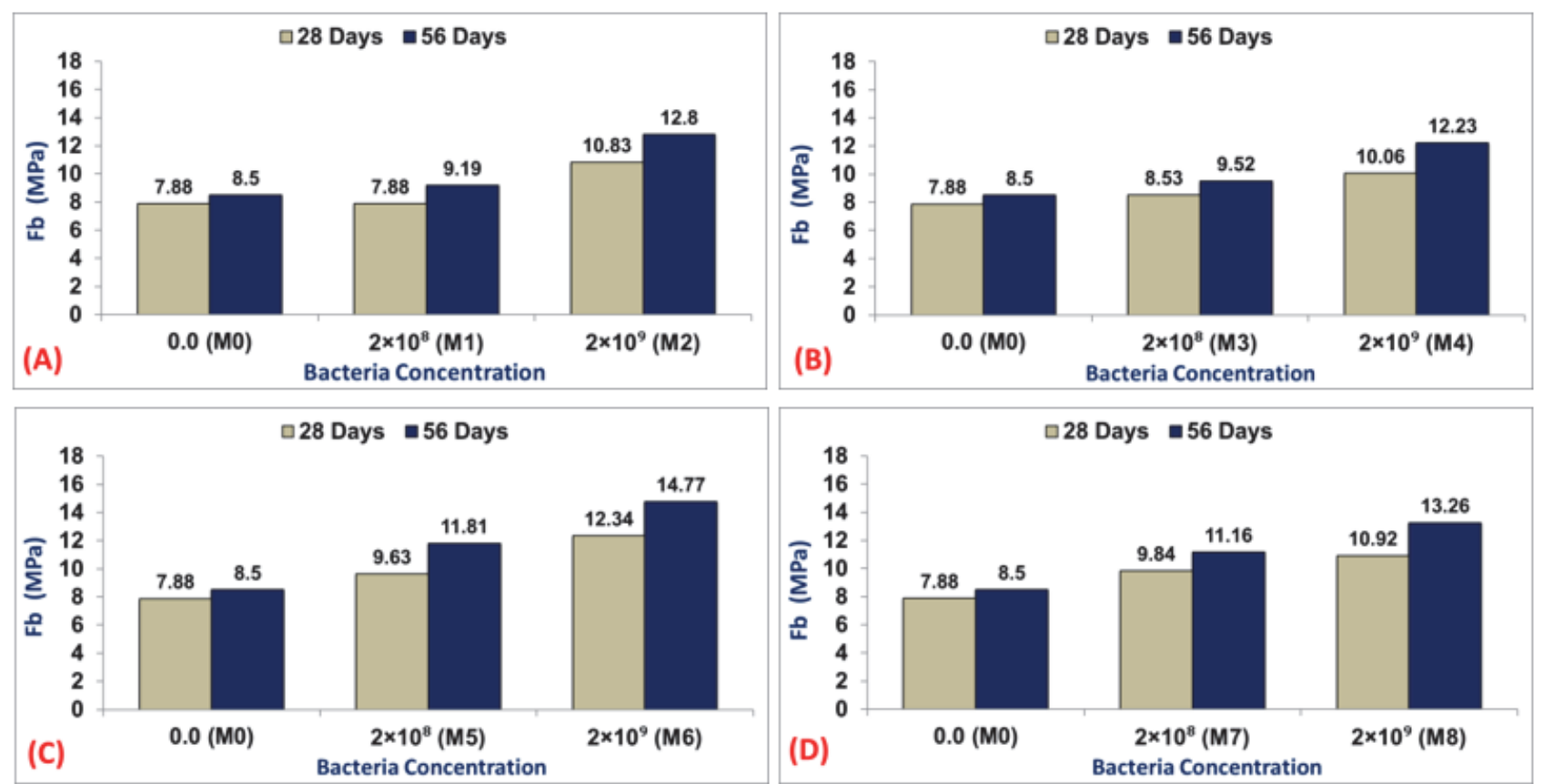

Figure 24: Effect of bacteria concentration on mortar bending strength for specimens without pre-cracking, at 7 days, 28 days, 56 days and 90 days: (A) Using 0.25\% BM, (B) Using 0.25\% EMCC, (C) Using 2.5\% BM and (D) Using 2.5\% EMCC.
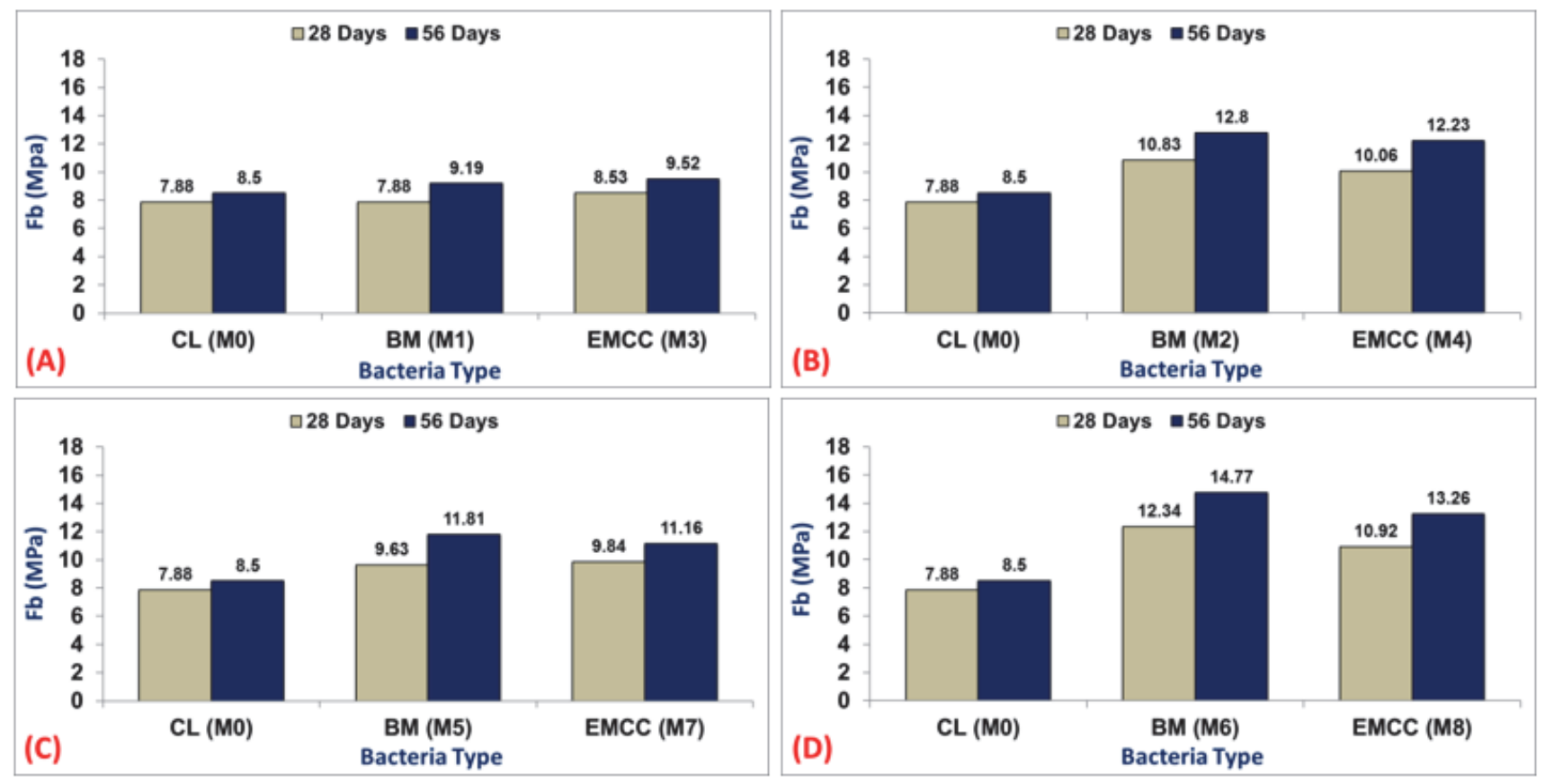


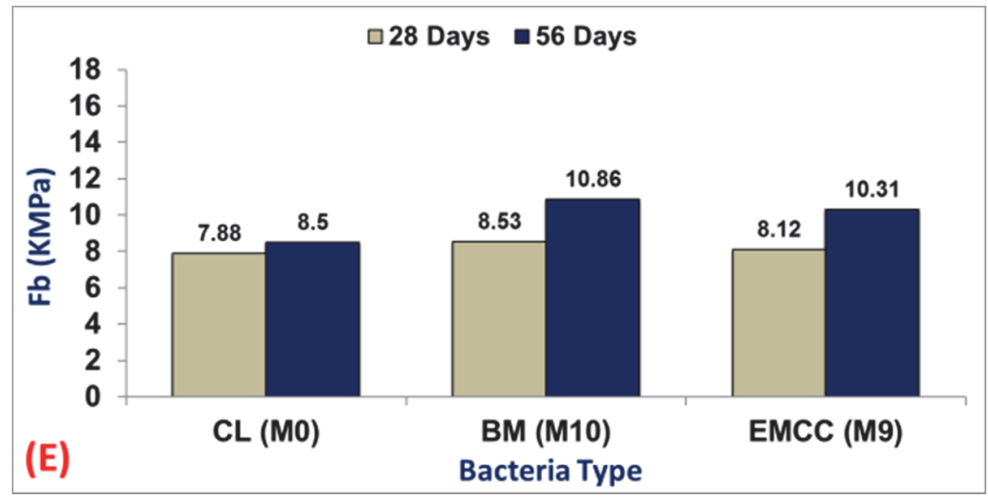

Figure 25: Effect of bacteria type on mortar bending strength for specimens without pre-cracking, at 7 days, 28 days, 56 days, and 90 days: (A) Using $0.25 \%$ bacteria with a concentration of $2 \times 10^{8}+0.50 \% \mathrm{Ca} \mathrm{La}$, (B) Using $0.25 \%$ bacteria with a concentration of $2 \times 10^{9}$ $+0.50 \% \mathrm{Ca} \mathrm{La},(\mathrm{C})$ Using $2.5 \%$ bacteria with a concentration of $2 \times 10^{8}+0.50 \% \mathrm{Ca} \mathrm{La}$, (D) Using $2.5 \%$ bacteria with a concentration of $2 \times 10^{9}+0.50 \% \mathrm{Ca} \mathrm{La}$ and (E) Using $0.25 \%$ bacteria with a concentration of $2 \times 10^{9}+0.50 \% \mathrm{Ca}$ Ac.

\section{EFFECT OF BACTERIA TYPE}

A $\mathrm{s}$ shown in Fig.25, the BM type was found to be more effective than the EMCC type. Using $2.5 \%$ bacteria with a concentration of $2 \times 10^{9} \mathrm{CFU} / \mathrm{ml}$ and $0.50 \% \mathrm{Ca} \mathrm{La}$, the gap between mix M6 and mix M8 is $1.42 \mathrm{MPa}$ at 28 days and $1.51 \mathrm{MPa}$ at 56 days. This increase was for the BM type. When the type of nutrient is changed to $\mathrm{Ca} A c$, the gap between mix M9 and mix M10 is $0.41 \mathrm{MPa}$ at 28 days and $0.55 \mathrm{MPa}$ at 56 days when using $2.5 \%$ bacteria with $2 \times 10^{9}$ $\mathrm{CFU} / \mathrm{ml}$ concentration and $0.5 \% \mathrm{Ca}$ Ac. The results are similar to those of other studies $[26,33,45]$.

\section{EFFECT OF NUTRIENT TYPE}

7 he variance between the two used nutrients' bending strength results is shown in Fig.26. Ca La shows more efficiency than $\mathrm{Ca}$ Ac. Using $0.25 \% \mathrm{BM}$ bacteria as an example, with $2 \times 10^{9} \mathrm{CFU} / \mathrm{ml}$ concentration, the gap between mix M2 and mix M10 is $2.3 \mathrm{MPa}$ at 28 days and $1.94 \mathrm{Mpa}$ at age 56 days. On the other hand, when the type of bacteria changed to EMCC, using $0.25 \%$ EMCC bacteria with $2 \times 10^{9} \mathrm{CFU} / \mathrm{ml}$ concentration, the gap between M4 and $\mathrm{M} 9$ was $1.94 \mathrm{MPa}$ at 28 days and $1.92 \mathrm{MPa}$ at age 56 days. The results similar to what was reported by other studies $[1,27,44]$.
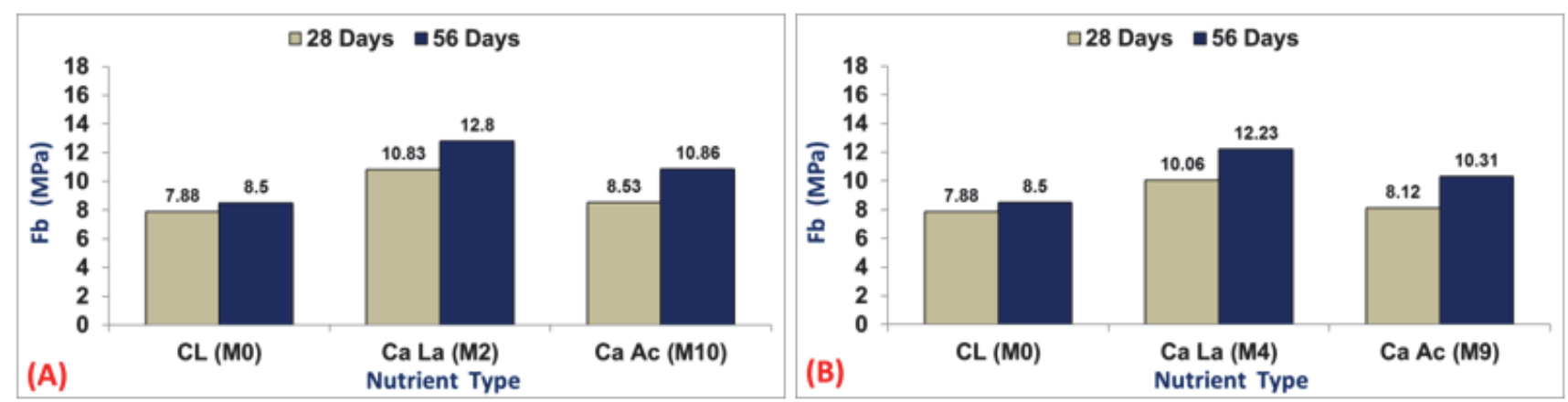

Figure 26: Effect of nutrient type on mortar bending strength for specimens without pre-cracking, at 7 days, 28 days, 56 days, and 90 days: (A) Using $0.25 \% \mathrm{BM}$ with a concentration of $2 \times 10^{9}$ and (B) using $0.25 \%$ EMCC with a concentration of $2 \times 10^{9}$. 


\section{SEM, EDS, TGA AND DTG RESULTS}

\section{Scanning electron microscope (SEM)}

EM test was used to examine mixes M6, M8, M12 and M13 compared with control mix M0. Both specimens of

$\mathrm{S}$ bacterial mortar and control mortar are checked using SEM to look for signs of microbial calcium carbonate precipitation, and the results are shown in Figs. 27:31. SEM test were carried out after 90 days of curing with the magnification of 1000X, 1500, 2000X, 2500X and 3000X. In comparison with the control mortar, the SEM results of the tested bacterial specimens showed fewer voids. Control mix specimens had many voids compared with bacterial mixes specimens, Also, bacterial specimens are denser in micro structures compared with control mix, this signifies that it improves the mortar's strength. It was observed that calcium carbonate and calcite crystals are formed by bacteria, leading to filling pores, while in control specimens were not observed significantly. Also, as the content of bacteria increases, the calcium carbonate content and calcite crystals increase, causing pores to fill. Calcium silicate hydrate (C-S-H) and ettringite as a result of cement hydration were also observed. The SEM analysis confirms the existence of calcite as well as higher levels of C-S-H in microbial mortars. These depositions in the pores increased the packing density of cement mortar, which improved its physicochemical and mechanical properties $[33,43,50]$.

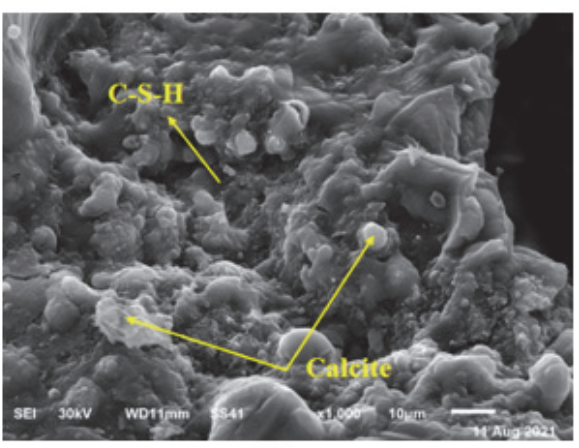

(A)

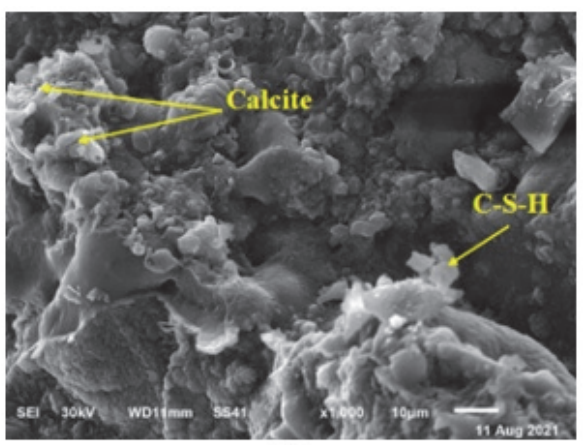

(B)

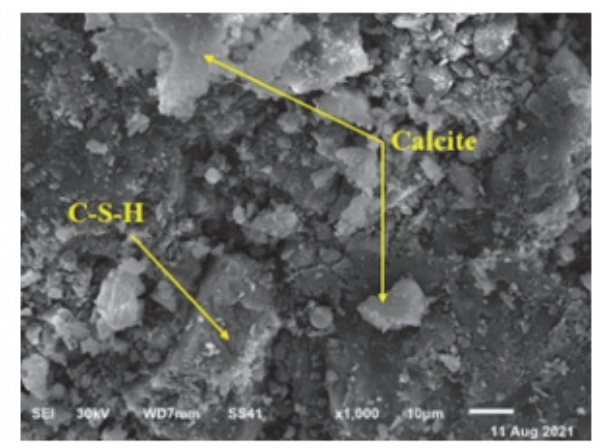

(C)

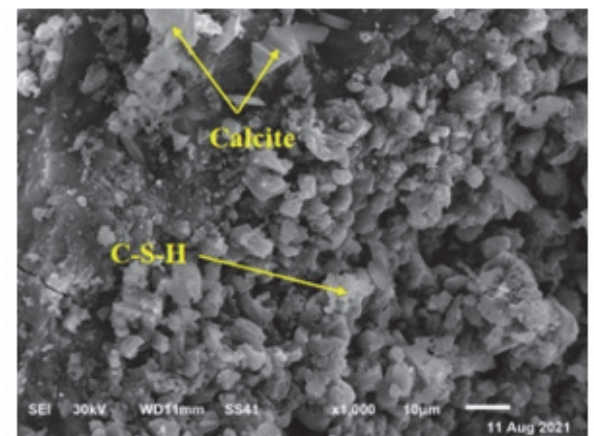

(D)

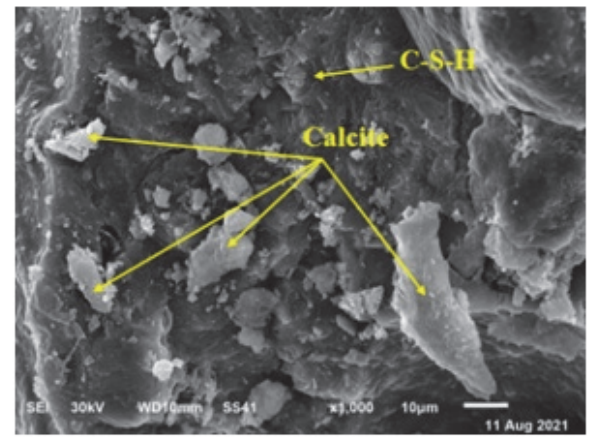

(E)

Figure 27: SEM images (1000X) after 90 days of curing for mixes (A) M0, (B) M12, (C) M13, (D) M8 and (E) M6.

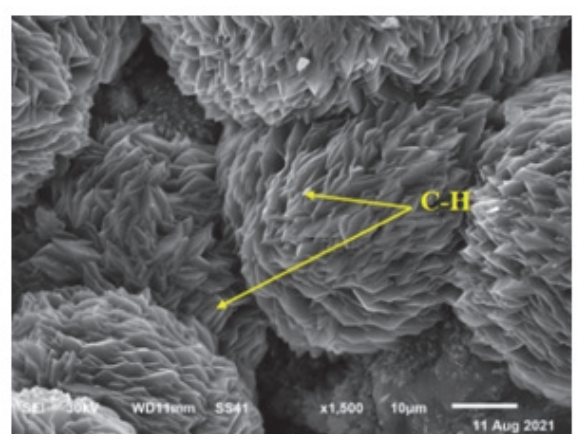

(A)

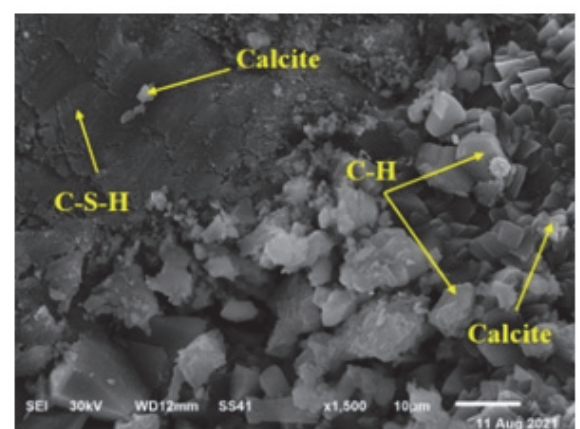

(B)

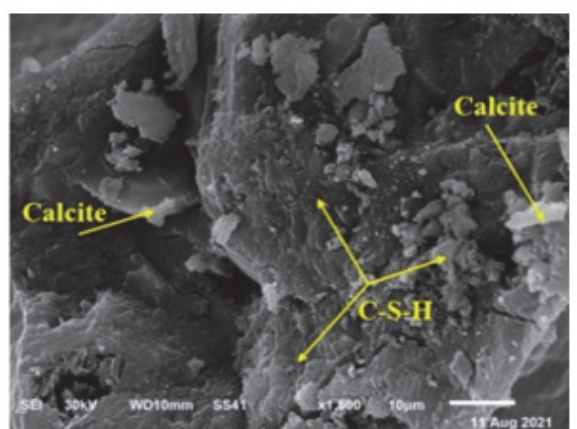

(C) 


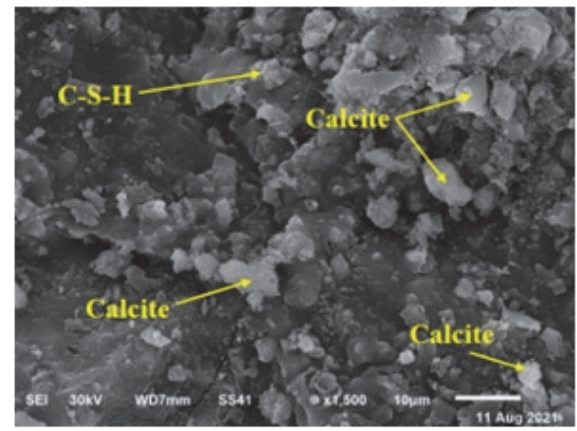

(D)

Figure 28: SEM images (1500X) after 90 days of curing for mixes (A) M0, (B) M13, (C) M8 and (D) M6.

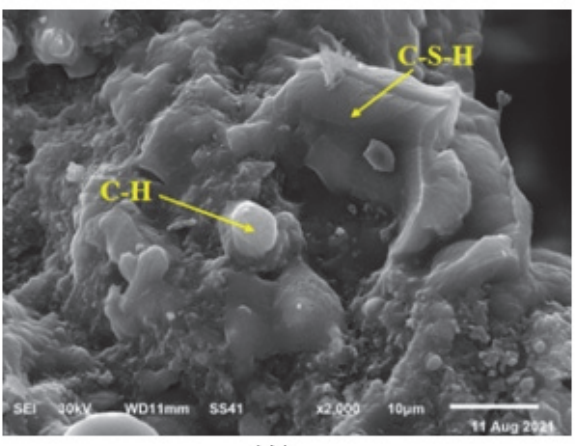

(A)

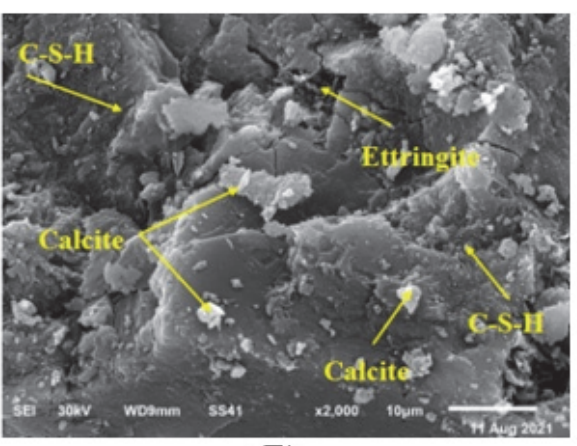

(B)

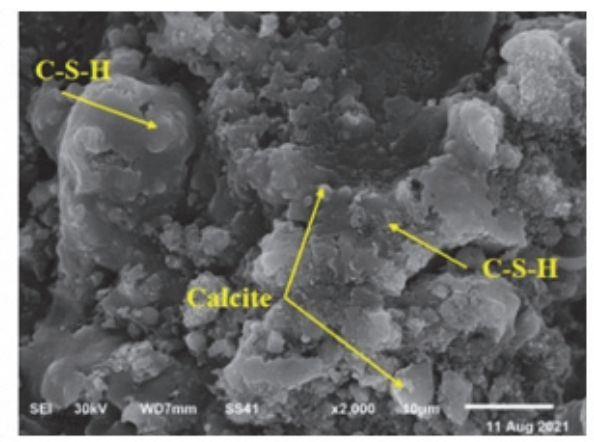

(C)

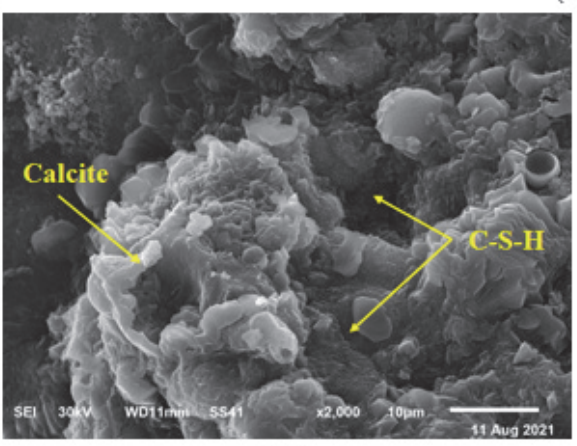

(D)

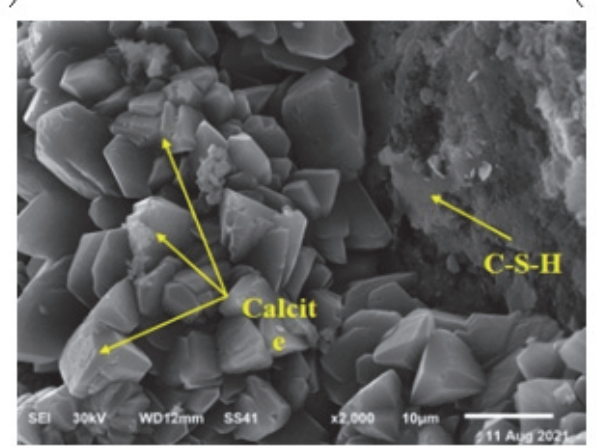

(E)

Figure 29: SEM images (2000X) after 90 days of curing for mixes (A) M0, (B) M12, (C) M13, (D) M8 and (E) M6.

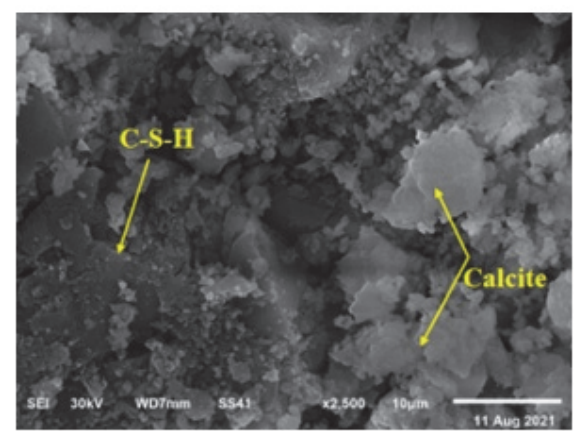

(A)

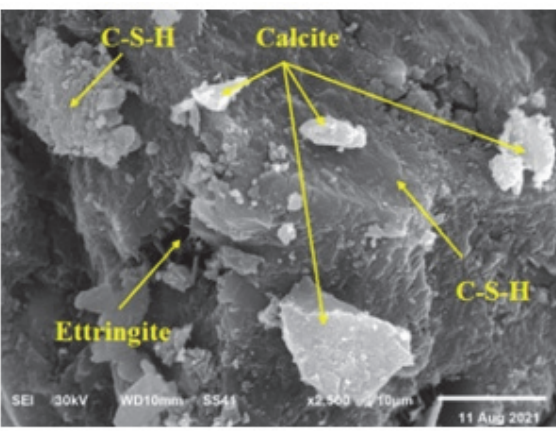

(B)

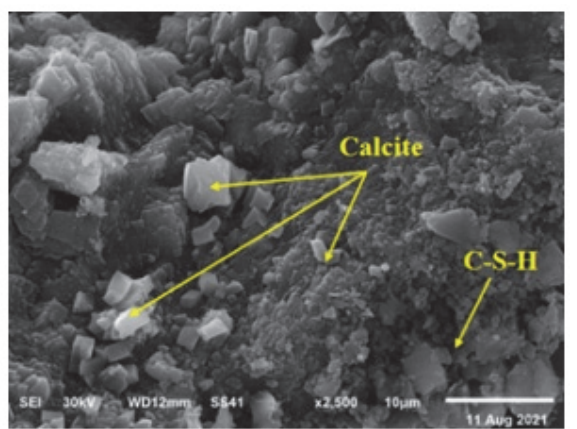

(C)

Figure 30: SEM images (2500X) after 90 days of curing for mixes (A) M13, (B) M8 and (C) M6. 


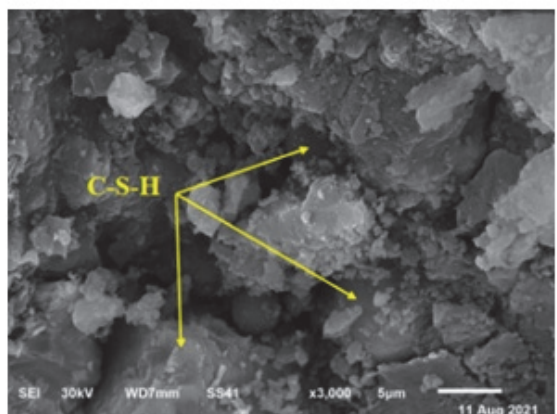

(A)

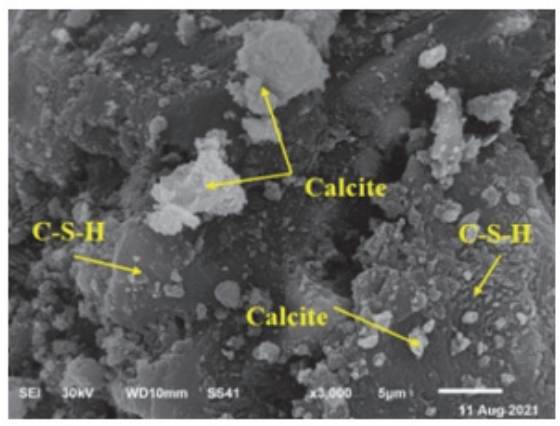

(B)

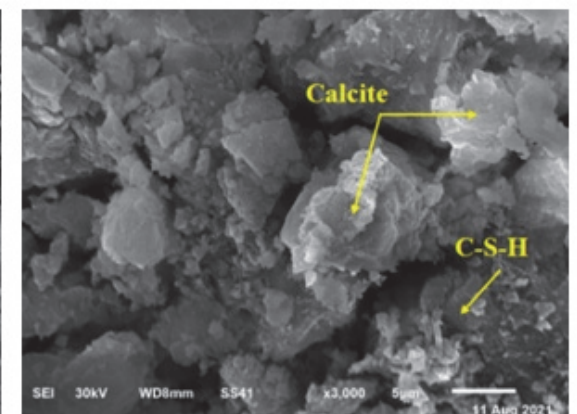

(C)

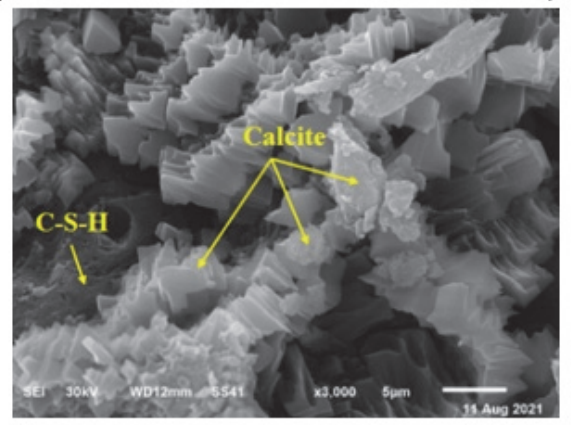

(D)

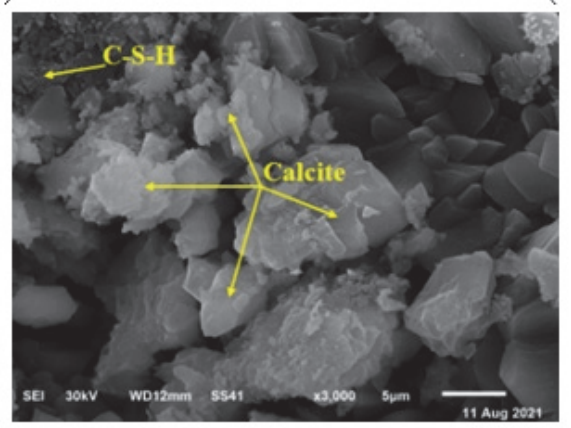

(E)

Figure 31: SEM images (3000X) after 90 days of curing for mixes (A) M0, (B) M12, (C) M13, (D) M8 and (E) M6.

\section{ENERGY DISPERSIVE SPECTROMETER (EDS)}

$\mathrm{I}$

$\mathrm{n}$ order to confirm the analysis, some mixes were tested in EDS to check the peaks of the chemical elements present in the sample as well as the formation of calcite. Calcium carbonate $(\mathrm{C})$, Oxygen $(\mathrm{O})$, Aluminium oxide (Al), Silicon dioxide $(\mathrm{Si})$ and Wollastonite $(\mathrm{Ca})$ are considered to be the main elemental components of mortar mixes. Also, the EDS result shows that the precipitate is composed of atoms of $\mathrm{Ca}, \mathrm{C}$, and $\mathrm{O}$ which verifies that the precipitate is calcium carbonate. EDS test results are shown in Fig.32 and Tab. 12. EDS results show that all specimens have calcium peaks, but the peaks are more when the bacteria spores are added and when bacteria content increases it increases more. For example, using $2.5 \%$ bacteria BM compared to control mix, calcium carbonate increased by $48.4 \%$, while $46.8 \%$ increased when using the EMCC content. When bacteria FP are used, the increase in calcium carbonate content compared to control mix is $10.85 \%$ and $22.59 \%$ when used with content of $0.5 \%$ and $2.5 \%$, respectively. The ratio of atomic $\%$ of $\mathrm{Ca} / \mathrm{Si}$ for tested mixes is one of the main indicators that has been observed. By increasing the ratio, it indicates that the mixture has a low compressive strength. For instance, the ratio of atomic $\%$ of $\mathrm{Ca} / \mathrm{Si}$ for control mix M6 was 0.52 when was 3.7 for control mix M0. These results are congruent with what has been reported by other researchers. $[15,22,43]$.

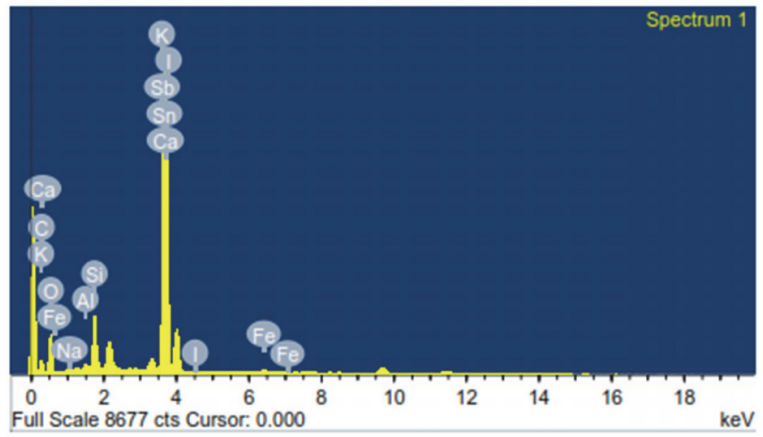

(A)

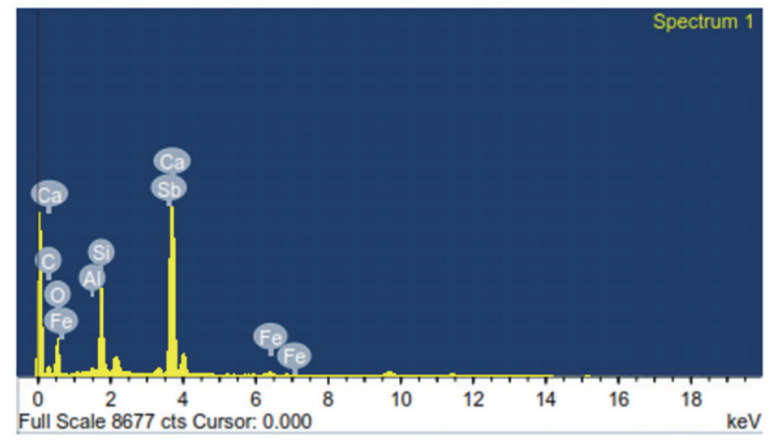

(B) 


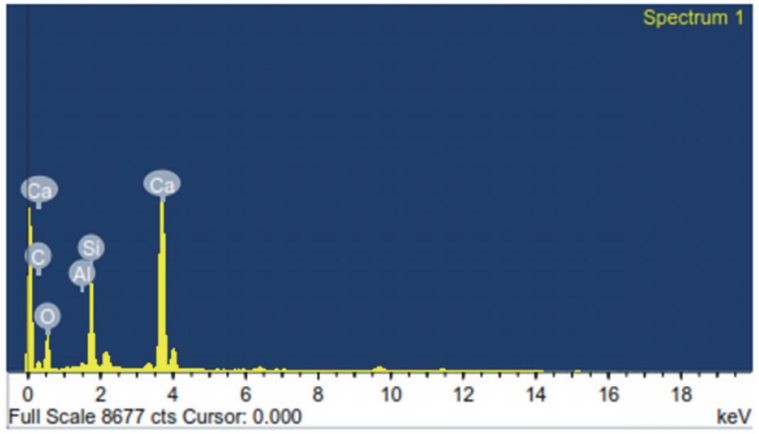

(C)

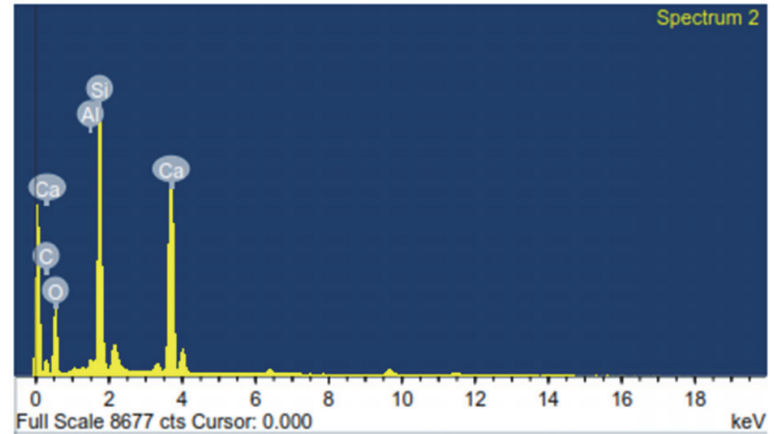

(D)

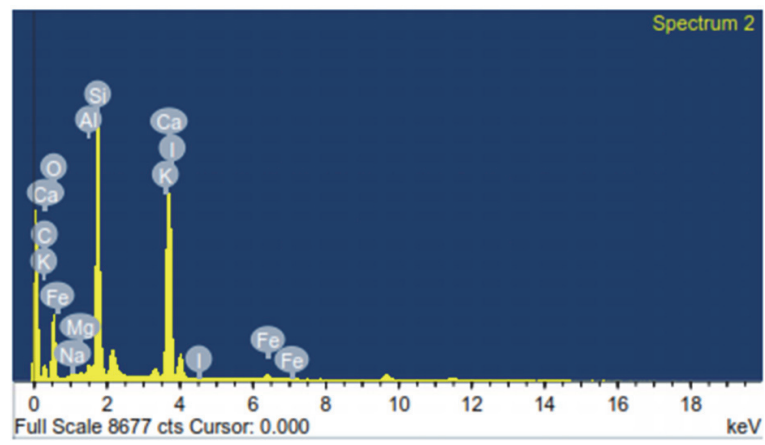

(E)

Figure 32: EDS spectra of mixes (A) M0, (B) M12, (C) M13, (D) M8 and (E) M6.

\begin{tabular}{ccccccccccc}
\hline & \multicolumn{2}{c}{ Mix M0 } & \multicolumn{2}{c}{ M12 } & \multicolumn{2}{c}{ M13 } & \multicolumn{2}{c}{ M8 } & \multicolumn{2}{c}{ M6 } \\
Element & Weight & Atomic & Weight & Atomic & Weight & Atomic & Weight & Atomic & Weight & Atomic \\
\% & $\%$ & $\%$ & $\%$ & $\%$ & $\%$ & $\%$ & $\%$ & $\%$ & $\%$ & $\%$ \\
C K & 11.24 & 21.81 & 12.46 & 20.52 & 13.78 & 20.94 & 16.5 & 24.51 & 16.68 & 25.19 \\
O K & 37.26 & 54.26 & 48.93 & 60.48 & 54.93 & 62.65 & 51.99 & 57.98 & 49.6 & 56.21 \\
Al K & 0.57 & 0.49 & 0.77 & 0.56 & 0.77 & 0.52 & 0.78 & 0.51 & 0.72 & 0.45 \\
Si K & 4.63 & 3.84 & 10.15 & 7.15 & 10.24 & 6.65 & 17.44 & 11.08 & 17.07 & 11.02 \\
Ca K & 24.46 & 14.22 & 20.21 & 9.97 & 20.28 & 9.24 & 13.29 & 5.92 & 12.77 & 5.78 \\
\hline
\end{tabular}

Table 12: Elemental composition of the control and bacterial mortar mixes from EDS analysis.

\section{THERMO GRAVIMETRIC ANALYSIS (TGA) AND DIFFERENTIAL THERMAL ANALYSIS (DTG)}

$\mathrm{T}$ hermo gravimetric analysis (TGA) was performed in order to assume chemically the degree of hydration of various mixtures, which was estimated by the difference in mass between 25 and $1000{ }^{\circ} \mathrm{C}$. The mass loss values have been obtained from the classical experiment (TGA) performed on cement pastes and then Hydration degree assessment of cement pastes was calculated [41]. Cement pastes' hydration degree calculated is presented in Fig.33. It can be noticed that the short-term hydration degree of mix M6 cement paste was rapidly increasing more than other mixes. The degree of hydration was found to be respectively $35.18,37.48$ and $39.64 \%$ at 28,56 and 90 days. In bacterial pastes, the results showed that the addition of bacteria significantly increased the hydration kinetics, particularly at 56 and 90 days. For instance, the addition of $2.5 \%$ of $\mathrm{BM}$ bacteria compared with control paste, increased the degree of hydration by respectively $14.96 \%, 16.39 \%$ and $16.62 \%$ for 28,56 and 90 days. Similarly, the use of $2.5 \%$ of FP bacteria increased the degree of hydration by respectively $5.39 \%, 6.37 \%$ and $5.12 \%$ for 28,56 and 90 days. This results from the fact that the degree of hydration is increased with an increase in calcite. The DTG thermograms of control and bacterial mortar specimens are shown in Figs.. 34:38. 


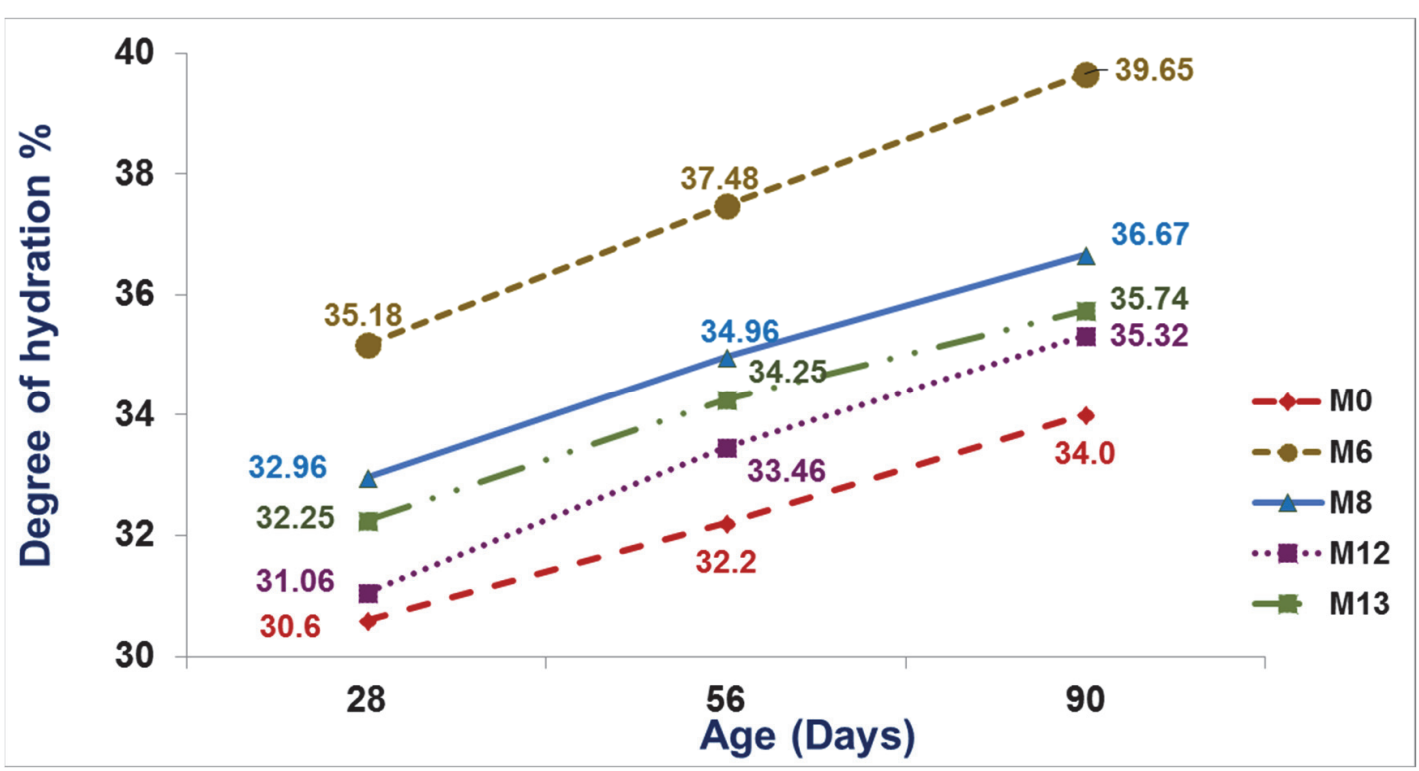

Figure 33: Hydration degree assessment of cement pastes.

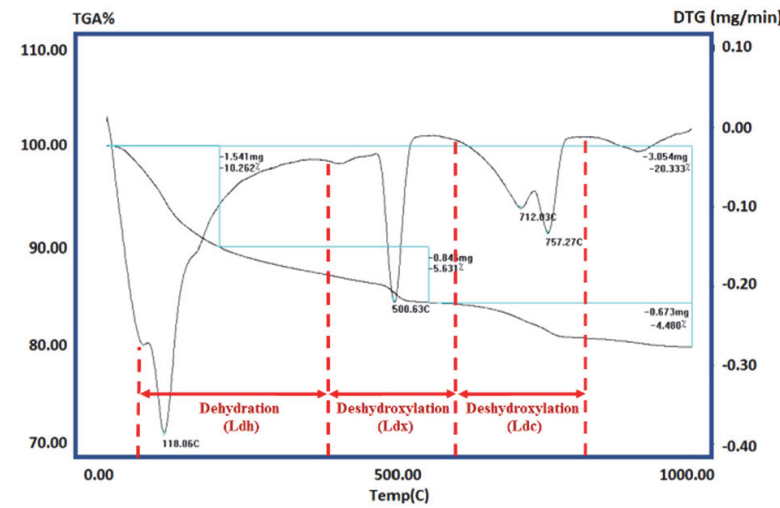

(A)

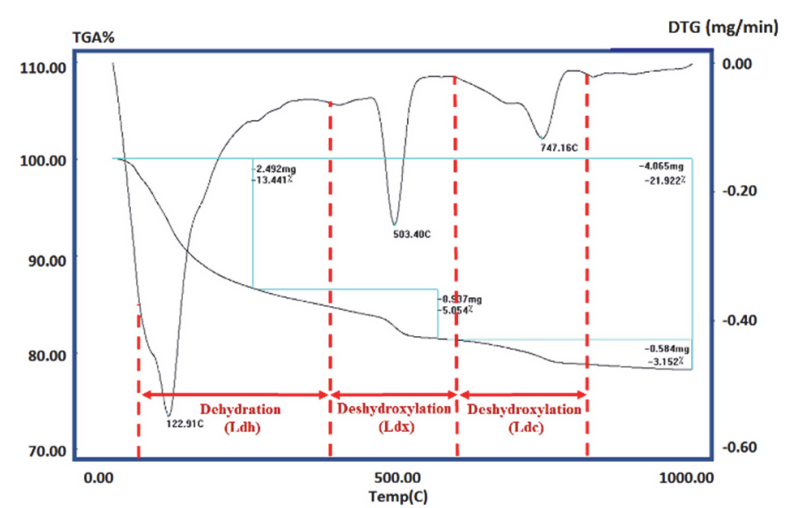

(B)

Figure 34: TGA/DTG of cement paste of mix M0 at the ages of (A) 28 days and (B) 90 days.

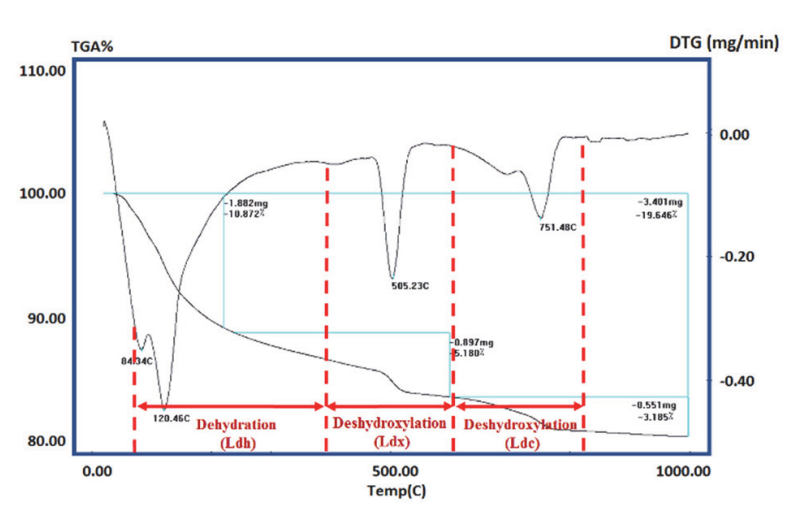

(A)

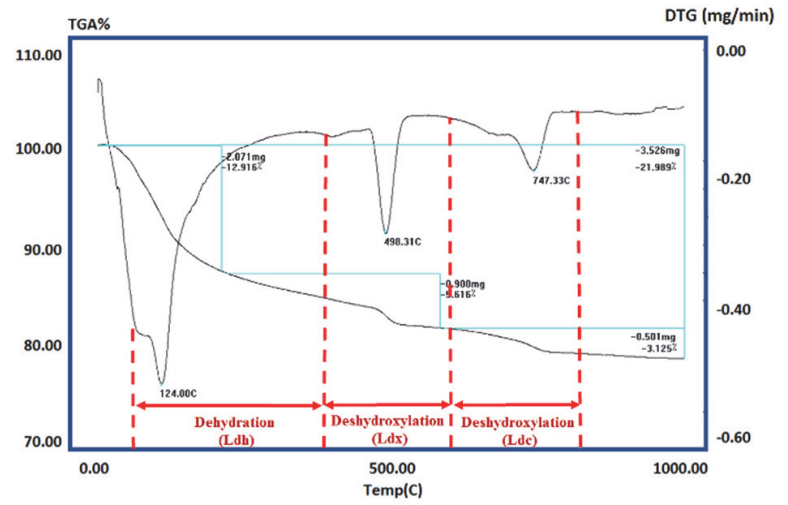

(B)

Figure 35: TGA/DTG of cement paste of mix M6 at the ages of (A) 28 days and (B) 90 days.. 


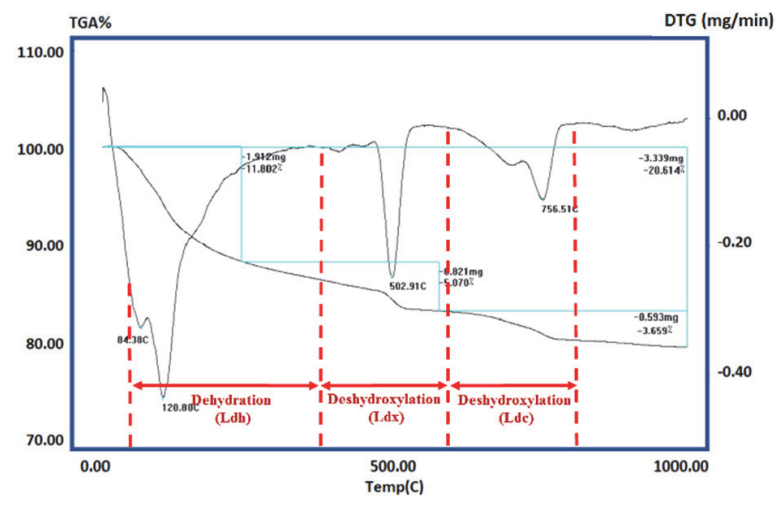

(A)

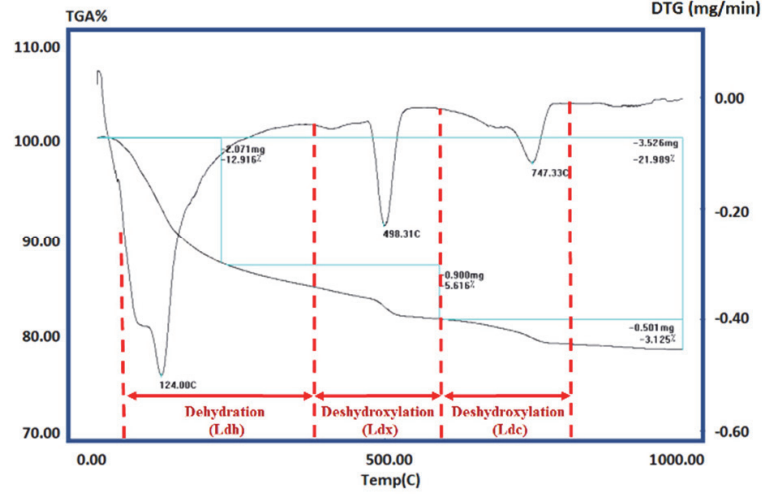

(B)

Figure 36: TGA/DTG of cement paste of mix M8 at the ages of (A) 28 days and (B) 90 days.

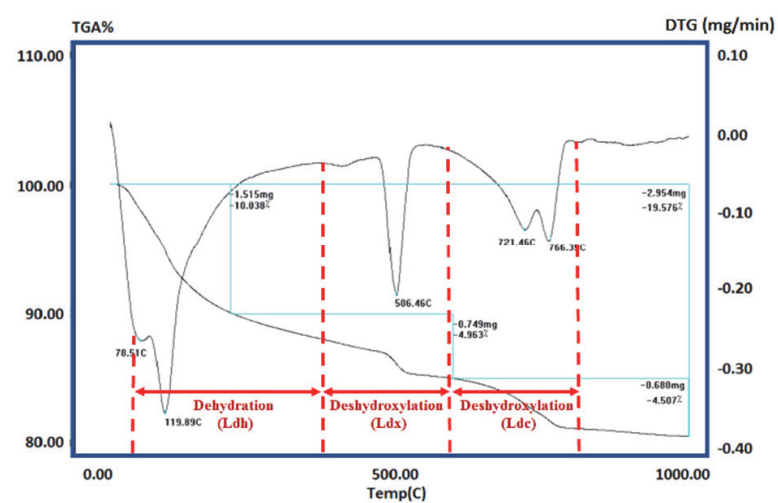

(A)

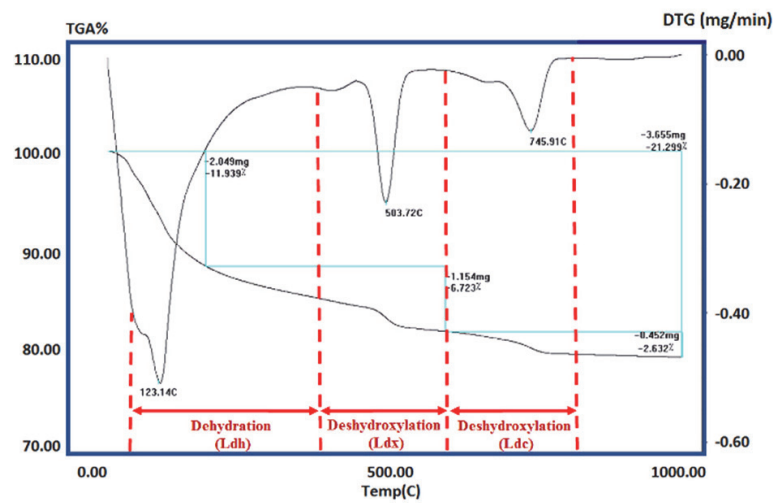

(B)

Figure 37: TGA/DTG of cement paste of mix M12 at the ages of (A) 28 days and (B) 90 days.

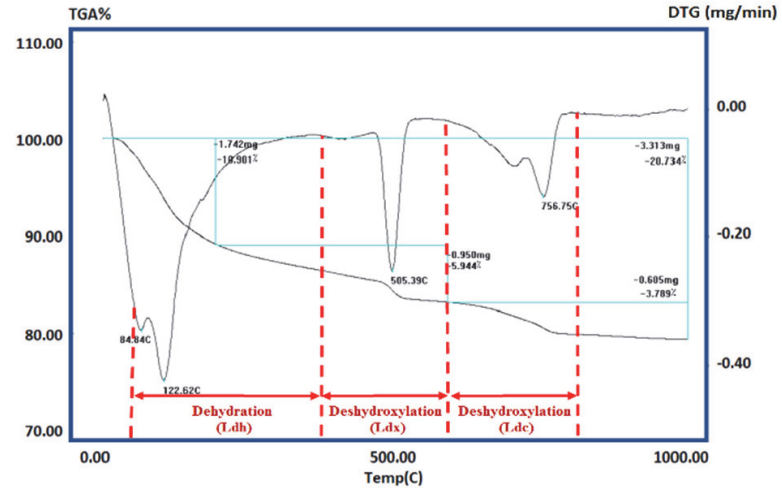

(A)

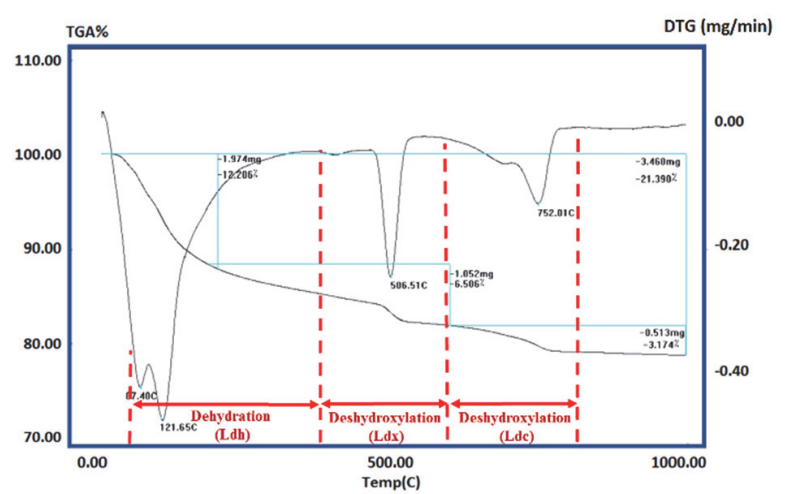

(B)

Figure 38: TGA/DTG of cement paste of mix M13 at the ages of (A) 28 days and (B) 90 days.

\section{CONCLUSIONS}

7 he current investigation provided an experimental program to study the effect of using bacteria on the mechanical properties of self-healing mortar. It involves adding two concentrations of the prepared bacterial suspension to two types of bacteria, Bacillus sphaericus and Bacillus Megaterium. Also, a third type of bacteria used, Bacillus 
subtilis, is encapsulated in calcium alginate beads, which are in the form of a ready-to-mix powder. The effects of bacteria type, bacteria content, bacteria concentration, and nutrient type on the properties of the self-healing mortar were observed. Also, the analysis of the mechanical behavior results were confirmed by SEM, EDS, and TGA/DTG tests. The following conclusions can be drawn according to the results of this study:

1. The mixes containing bacteria in all ages have a higher compressive and bending strength than their control mix.

2. The best results in the increase in compressive strength reached $47.6 \%, 65.2 \%, 61 \%$, and $58.8 \%$ at ages $7,28,56$, and 90 days respectively in mix M6, which contains $2.5 \%$ bacteria BM with $2 \times 109 \mathrm{CFU} / \mathrm{ml}$ concentration and $0.5 \%$ Ca La compared with control mix M0.

3. The best results in the increase in bending strength reached $68 \%$, and $108.5 \%$ at ages 28 , and 56 days respectively in mix M14, which contains 5\% bacteria FP compared with control mix M0.

4. The compressive strength and bending strength results are larger when the bacteria concentration increases to $2 \times 10^{9} \mathrm{CFU} / \mathrm{ml}$ and when the bacteria content increases. Also, using BM was more effective than using EMCC.

5. The results of the compressive strength test for reloaded cracked specimens of bacterial mortar indicated that there was an increase in strength when compared to the specimens without pre-cracking of the same mix at the ages of 28, 56, and 90 days. The best recovery of compressive strength results was for M6. The results showed that using bacteria increased the compressive strength of reloaded cracked specimens so close to that of specimens without pre-cracking when compared to control mix, with percentages reaching $82 \%, 89.2 \%$, and $98.77 \%$ of ultimate compressive strength at the ages of 28,56 , and 90 days for M6 using bacteria BM, respectively.

6. For both $\mathrm{BM}$ and EMCC, using $0.50 \%$ bacteria with a $2 \times 10^{9} \mathrm{CFU} / \mathrm{ml}$ concentration is better than using $2.50 \%$ bacteria with a $2 \times 10^{8} \mathrm{CFU} / \mathrm{ml}$ concentration. The increase in compressive strength was attributed to calcite precipitation on the bacteria cell surfaces within the pores, as observed by SEM and verified by EDX.

7. The use of the FP type, which is in the form of ready-mix powder, is practically easier on site than the use of a $\mathrm{BM}$ or EMCC type and, at the same time, is given very close behavior.

\section{REFERENCES}

[1] Mutitu, D.K., Wachira, J.M., Mwirichia, R., Thiong'o, J.K., Munyao, O.M. and Muriithi, G., (2019). Influence of Lysinibacillus sphaericus on compressive strength and water sorptivity in microbial cement mortar. Heliyon, 5(11), p.e02881. DOI: $10.1016 /$ j.heliyon.2019.e02881.

[2] Wachira, J.M., Thiong'o, J.K., Marangu, J.M. and Murithi, L.G., (2019). Physicochemical performance of portland-rice husk ash-calcined clay-dried acetylene lime sludge cement in sulphate and chloride media. Advances in Materials Science and Engineering, DOI: 10.1155/2019/5618743.

[3] Khaliq, W. and Ehsan, M.B., (2016). Crack healing in concrete using various bio influenced self-healing techniques. Construction and Building Materials, 102, pp.349-357. DOI: 10.1016/j.conbuildmat.2015.11.006.

[4] Zhang, L.V., Suleiman, A.R. and Nehdi, M.L., (2020). Self-healing in fiber-reinforced alkali-activated slag composites incorporating different additives. Construction and Building Materials, 262, p.120059.

DOI: $10.1016 /$ j.conbuildmat.2020.120059.

[5] Nguyen, T.H., Ghorbel, E., Fares, H. and Cousture, A., (2019). Bacterial self-healing of concrete and durability assessment. Cement and Concrete Composites, 104, p.103340. DOI: 10.1016/j.cemconcomp.2019.103340.

[6] Luo, M. and Qian, C., (2016). Influences of bacteria-based self-healing agents on cementitious materials hydration kinetics and compressive strength. Construction and Building Materials, 121, pp.659-663.

DOI: $10.1016 /$ j.conbuildmat.2016.06.075.

[7] Qian, C., Yu, X. and Wang, X., (2018). A study on the cementation interface of bio-cement. Materials Characterization, 136, pp.122-127. DOI: 10.1016/j.matchar.2017.12.011.

[8] Verma, R.K., Chaurasia, L., Bisht, V. and Thakur, M., (2015). Bio-mineralization and bacterial carbonate precipitation in mortar and concrete. Biosci Bioeng, 1, pp.5-11.

[9] Maes, M. and De Belie, N., (2016), September. Service life estimation of cracked and healed concrete in marine environment. In Concrete Solutions: Proceedings of Concrete Solutions, 6th International Conference on Concrete Repair, Thessaloniki, Greece, 20-23 June 2016 (p. 409). CRC Press.

[10] Algaifi, H.A., Bakar, S.A., Sam, A.R.M., Ismail, M., Abidin, A.R.Z., Shahir, S. and Altowayti, W.A.H., (2020). Insight into the role of microbial calcium carbonate and the factors involved in self-healing concrete. Construction and Building Materials, 254, p.119258. DOI: 10.1016/j.conbuildmat.2020.119258. 
[11] Schwantes-Cezario, N., Peres, M.V.N.D.N., Fruet, T.K., Nogueira, G.S.F., Toralles, B.M. and Cezario, D.D.S., (2018). Crack filling in concrete by addition of Bacillus subtilis spores-Preliminary study. Dyna, 85(205), pp.132-139. DOI: 10.15446/dyna.v85n205.68591.

[12] Vijay, K., Murmu, M. and Deo, S.V., (2017). Bacteria based self healing concrete-A review. Construction and Building Materials, 152, pp.1008-1014. DOI: 10.1016/j.conbuildmat.2017.07.040.

[13] Rauf, M., Khaliq, W., Khushnood, R.A. and Ahmed, I., (2020). Comparative performance of different bacteria immobilized in natural fibers for self-healing in concrete. Construction and Building Materials, 258, p.119578. DOI: 10.1016/j.conbuildmat.2020.119578.

[14] Gupta, S., Dai Pang, S. and Kua, H.W., (2017). Autonomous healing in concrete by bio-based healing agents-A review. Construction and Building Materials, 146, pp.419-428. DOI: 10.1016/j.conbuildmat.2017.04.111.

[15] Andalib, R., Abd Majid, M.Z., Hussin, M.W., Ponraj, M., Keyvanfar, A., Mirza, J. and Lee, H.S., (2016). Optimum concentration of Bacillus megaterium for strengthening structural concrete. Construction and Building Materials, 118, pp.180-193. DOI: 10.1016/j.conbuildmat.2016.04.142.

[16] Bhaskar, S., Hossain, K.M.A., Lachemi, M., Wolfaardt, G. and Kroukamp, M.O., (2017). Effect of self-healing on strength and durability of zeolite-immobilized bacterial cementitious mortar composites. Cement and Concrete Composites, 82, pp.23-33. DOI: 10.1016/j.cemconcomp.2017.05.013

[17] Wang, J., Mignon, A., Trenson, G., Van Vlierberghe, S., Boon, N. and De Belie, N., (2018). A chitosan based pHresponsive hydrogel for encapsulation of bacteria for self-sealing concrete. Cement and Concrete Composites, 93, pp.309-322. DOI: 10.1016/j.cemconcomp.2018.08.007.

[18] Williams, S.L., Sakib, N., Kirisits, M.J. and Ferron, R.D., (2016). Flexural Strength Recovery Induced by Vegetative Bacteria Added to Mortar. ACI Materials Journal, 113(4). DOI: 10.14359/51688831.

[19] De Belie, N. and Wang, J. (2015). Bacteria-based repair and self-healing of concrete. Journal of Sustainable CementBased Materials, 5(1-2), pp.35-56. DOI: 10.1080/21650373.2015.1077754.

[20] Algaifi, H.A., Bakar, S.A., Sam, A.R.M., Ismail, M., Abidin, A.R.Z., Shahir, S. and Altowayti, W.A.H., (2020). Insight into the role of microbial calcium carbonate and the factors involved in self-healing concrete. Construction and Building Materials, 254, p.119258. DOI: 10.1016/j.conbuildmat.2020.119258.

[21] Ruan, S., Qiu, J., Weng, Y., Yang, Y., Yang, E.H., Chu, J. and Unluer, C., (2019). The use of microbial induced carbonate precipitation in healing cracks within reactive magnesia cement-based blends. Cement and Concrete Research, 115, pp.176-188. DOI: 10.1016/j.cemconres.2018.10.018.

[22] Parashar, A.K. and Gupta, A., (2021), April. Experimental study of the effect of bacillus megaterium bacteria on cement concrete. In IOP Conference Series: Materials Science and Engineering, 1116(1), p. 012168). IOP Publishing. DOI: $10.1088 / 1757-899 x / 1116 / 1 / 012168$.

[23] Mondal, S. and Ghosh, A.D., (2021). Spore-forming Bacillus subtilis vis-à-vis non-spore-forming Deinococcus radiodurans, a novel bacterium for self-healing of concrete structures: a comparative study. Construction and Building Materials, 266, p.121122. DOI: 10.1016/j.conbuildmat.2020.121122.

[24] Reddy, B.M.S. and Revathi, D., (2019). An experimental study on effect of Bacillus sphaericus bacteria in crack filling and strength enhancement of concrete. Materials Today: Proceedings, 19, pp.803-809.

DOI: 10.1016/j.matpr.2019.08.135.

[25] Priya, T.S., Ramesh, N., Agarwal, A., Bhusnur, S. and Chaudhary, K., (2019). Strength and durability characteristics of concrete made by micronized biomass silica and Bacteria-Bacillus sphaericus. Construction and Building Materials, 226, pp.827-838. DOI: 10.1016/j.conbuildmat.2019.07.172.

[26] Nain, N., Surabhi, R., Yathish, N.V., Krishnamurthy, V., Deepa, T. and Tharannum, S., (2019). Enhancement in strength parameters of concrete by application of Bacillus bacteria. Construction and Building Materials, 202, pp.904908. DOI: 10.1016/j.conbuildmat.2019.01.059.

[27] Irwan, J.M., Anneza, L.H., Othman, N., Alshalif, A.F., Zamer, M.M. and Teddy, T., (2016). Calcium Lactate addition in Bioconcrete: Effect on Compressive strength and Water penetration. In MATEC Web of Conferences, 78, p. 01027). EDP Sciences. DOI: 10.1051/matecconf/20167801027.

[28] Gonzalez, A., Parraguez, A., Corvalan, L., Correa, N., Castro, J., Stuckrath, C. and Gonzalez, M., (2020). Evaluation of Portland and Pozzolanic cement on the self-healing of mortars with calcium lactate and bacteria. Construction and Building Materials, 257, p.119558. DOI: 10.1016/j.conbuildmat.2020.119558.

[29] Su, Y., Feng, J., Jin, P. and Qian, C., (2019). Influence of bacterial self-healing agent on early age performance of cement-based materials. Construction and Building Materials, 218, pp.224-234.

DOI: 10.1016/j.conbuildmat.2019.05.077. 
[30] Khaliq, W. and Ehsan, M.B., (2016). Crack healing in concrete using various bio influenced self-healing techniques. Construction and Building Materials, 102, pp.349-357. DOI: 10.1016/j.conbuildmat.2015.11.006.

[31] Sahoo, K.K., Sathyan, A.K., Kumari, C., Sarkar, P. and Davis, R., (2016). Investigation of cement mortar incorporating Bacillus sphaericus. International Journal of Smart and Nano Materials, 7(2), pp.91-105. DOI: $10.1080 / 19475411.2016 .1205157$.

[32] Chaurasia, L., Bisht, V., Singh, L.P. and Gupta, S., (2019). A novel approach of biomineralization for improving micro and macro-properties of concrete. Construction and Building Materials, 195, pp.340-351. DOI: 10.1016/j.conbuildmat.2018.11.031.

[33] Nagarajan, V., Prabhu, T.K., Shankar, M.G. and Jagadesh, P., (2017). A study on the strength of the bacterial concrete embedded with bacillus megaterium. International Research Journal of Engineering and Technology, 4(12), pp.17841788.

[34] Kalhori, H. and Bagherpour, R., (2017). Application of carbonate precipitating bacteria for improving properties and repairing cracks of shotcrete. Construction and Building Materials, 148, pp.249-260. DOI: 10.1016/j.conbuildmat.2017.05.074.

[35] Siddique, R., Singh, K., Singh, M., Corinaldesi, V. and Rajor, A., (2016). Properties of bacterial rice husk ash concrete. Construction and Building materials, 121, pp.112-119. DOI: 10.1016/j.conbuildmat.2016.05.146

[36] Achal, V., Mukerjee, A. and Reddy, M.S., (2013). Biogenic treatment improves the durability and remediates the cracks of concrete structures. Construction and Building Materials, 48, pp.1-5. DOI: 10.1016/j.conbuildmat.2013.06.061.

[37] E.S.S. No. 1109, (2008) "Aggregate", Egyptian Standard Specification, Ministry of Industry, Cairo, Egypt.

[38] Admixture, H. High Range Water-Reducing. "ASTM C 494, Type F/G."

[39] ECP 203-2016 (2016), Egyptian Code, Housing and Building Research Center, Cairo, Egypt

[40] EN, T., 2016. 196-1: 2016. Methods of testing cement-Part, 1.

[41] Deboucha, W., Leklou, N., Khelidj, A. and Oudjit, M.N., (2017). Hydration development of mineral additives blended cement using thermogravimetric analysis (TGA): Methodology of calculating the degree of hydration. Construction and Building Materials, 146, pp.687-701. DOI: 10.1016/j.conbuildmat.2017.04.132.

[42] Chahal, N., Siddique, R. and Rajor, A., (2012). Influence of bacteria on the compressive strength, water absorption and rapid chloride permeability of fly ash concrete. Construction and Building Materials, 28(1), pp.351-356. DOI: 10.1016/j.conbuildmat.2011.07.042.

[43] Souid, A., Esaker, M., Elliott, D. and Hamza, O., (2019). Experimental data of bio self-healing concrete incubated in saturated natural soil. Data in brief, 26, p.104394. DOI: 10.1016/j.dib.2019.104394.

[44] Chaerun, S.K., Syarif, R. and Wattimena, R.K. (2020). Bacteria incorporated with calcium lactate pentahydrate to improve the mortar properties and self-healing occurrence. Scientific Reports, 10(1). DOI: $10.1038 / \mathrm{s} 41598-020-74127-4$.

[45] Abo-El-Enein, S.A., Ali, A.H., Talkhan, F.N. and Abdel-Gawwad, H.A., (2013). Application of microbial biocementation to improve the physico-mechanical properties of cement mortar. HBRC Journal, 9(1), pp.36-40. DOI: 10.1016/j.hbrcj.2012.10.004.

[46] Andalib, R., Abd Majid, M.Z., Keyvanfar, A., Talaiekhozan, A., Hussin, M.W., Shafaghat, A., Zin, R.M., Lee, C.T., Fulazzaky, M.A. and Ismail, H.H., (2014). Durability improvement assessment in different high strength bacterial structural concrete grades against different types of acids. Sadhana, 39(6), pp.1509-1522. DOI: $10.1007 / \mathrm{s} 12046-014-0283-0$.

[47] Mutitu, K.D., Munyao, M.O., Wachira, M.J., Mwirichia, R., Thiong'o, K.J. and Marangu, M.J., (2019). Effects of biocementation on some properties of cement-based materials incorporating Bacillus Species bacteria-a review. Journal of Sustainable Cement-Based Materials, 8(5), pp.309-325. DOI: 10.1080/21650373.2019.1640141.

[48] Erşan, Y.Ç., Hernandez-Sanabria, E., Boon, N. and De Belie, N., (2016). En hanced crack closure performance of microbial mortar through nitrate reduction. Cement and concrete composites, 70, pp.159-170. DOI: 10.1016/j.cemconcomp.2016.04.001

[49] Mutitu, D.K., Wachira, J.M., Mwirichia, R., Thiong'o, J.K., Munyao, O.M. and Genson, M., (2020). Biocementation Influence on Flexural Strength and Chloride Ingress by Lysinibacillus sphaericus and Bacillus megaterium in Mortar Structures. Journal of Chemistry, 2020. DOI: 10.1016/j.cemconcomp.2016.04.001.

[50] Pei, R., Liu, J., Wang, S. and Yang, M., (2013). Use of bacterial cell walls to improve the mechanical performance of concrete. Cement and Concrete Composites, 39, pp.122-130. DOI: 10.1016/j.cemconcomp.2013.03.024. 